\title{
Cognitive Neuroscience Analyses of Memory: A Historical Perspective
}

\section{Citation}

Polster, Michael R., Lynn Nadel, and Daniel L. Schacter. 1991. Cognitive neuroscience analyses of memory: A historical perspective. Journal of Cognitive Neuroscience 3(2): 95-116.

\section{Published Version}

doi:10.1162/jocn.1991.3.2.95

\section{Permanent link}

http://nrs.harvard.edu/urn-3:HUL.InstRepos:3622258

\section{Terms of Use}

This article was downloaded from Harvard University's DASH repository, and is made available under the terms and conditions applicable to Other Posted Material, as set forth at http:// nrs.harvard.edu/urn-3:HUL.InstRepos:dash.current.terms-of-use\#LAA

\section{Share Your Story}

The Harvard community has made this article openly available.

Please share how this access benefits you. Submit a story.

Accessibility 


\title{
Cognitive Neuroscience Analyses of Memory: A Historical Perspective
}

\author{
Michael R. Polster, \\ Lynn Nadel, and Daniel L. Schacter \\ Department of Psychology \\ University of Arizona
}

\begin{abstract}
As part of the general trend toward interdisciplinary research in recent years, a growing number of investigators have come to consider both cognitive and neuroscientific perspectives when theorizing about memory. Although such cognitive neuroscience analyses are a relatively recent development, the approach has precedents in earlier scientific thinking about memory. In this article we present a historical review of three major issues in memory research-consolidation processes, the nature of memory representations, and multiple memory systems. We discuss the nature of the relation between cognitive
\end{abstract}

and neuroscientific approaches to each of these issues with respect to the distinction between collateral, complementary, and convergent relations (Schacter, 1986). Although some early investigators offered analyses that linked psychological and physiological perspectives, there is little historical evidence of systematic or sustained interdisciplinary research. However, more recent work, especially with respect to hypotheses about memory systems, suggests progress toward establishing programmatic interdisciplinary research.

Cognitive neuroscience is a fundamentally interdisciplinary pursuit that draws on the methodological tools and theoretical frameworks of both of its constituent disciplines. In doing so, it promises to provide a more complete understanding of mnemonic processes than could be achieved by either discipline alone. During the past few decades, the cognitive neuroscience approach has become increasingly prominent in the analysis of memory. A growing number of cognitive scientists have made use of findings and ideas about brain function (e.g., Schacter, 1985a; McClelland and Rumelhart, 1986a, 1986b; Shimamura, 1989), and similarly an increasing number of neuroscientists have drawn on cognitive theories and paradigms (e.g., Kean \& Nadel, 1982; Mishkin \& Petri, 1984; Squire, 1987). Although still in its infancy, this approach has already begun to yield important insights into various aspects of memory, and there is every reason to believe that it will become even more prominent in the future.

Although the emergence of widespread interest in cognitive neuroscience analyses of memory is a relatively recent phenomenon, the approach itself is not entirely without precedent in the history of scientific thinking about memory. Thus, for example, investigators such as Ribot (1882), Burnham (1903), Semon (1904/1921),
Hebb (1949), and even Freud (1895; in Bonaparte, Freud, \& Kris, 1954) put forward what could be broadly construed as memory theories that drew on both psychological and physiological perspectives. ${ }^{1}$ Nevertheless, we are not aware of any scholarly attempt to trace systematically the extent to which memory researchers have attempted to combine these two approaches. The main purpose of this article is to provide the beginnings of such an analysis.

There are several reasons why such a historical analysis is worth pursuing. First, there is simple intellectual curiosity about the antecedents to what is now an established trend in memory research. Second, the early investigators who attempted to develop cognitive neuroscience analyses should be recognized for their efforts. Third, and most importantly, examining previous interactions between psychological and physiological approaches may provide useful insights and lessons for contemporary researchers, showing how progress toward resolving critical issues in the domain of memory can often be made most easily within an interdisciplinary framework.

Instead of attempting to provide a comprehensive historical analysis, we have focused on three issues that have been, and continue to be, major problems of inter- 
est: consolidation processes, the nature of memory representations, and multiple memory systems. The paper is divided into three main sections that are devoted to each of these issues, respectively. Within each section, we provide a historical overview of the cognitive and neuroscientific approaches to the issue, discuss the nature and extent of interdisciplinary interactions, and assess the degree to which the two approaches have influenced each other.

We will consider the interactions (or lack of them) between cognitive and neuroscientific approaches to memory in terms of a distinction between collateral, complementary, and converging relations between research methodologies (Schacter, 1986). Collateral relations refer to situations in which two or more approaches to a particular issue are pursued independently, with little or no interaction. Complementary relations, in contrast, are observed when the analysis of a phenomenon in one discipline can usefully supplement the analysis of a similar phenomenon in another discipline. Finally, convergent relations refer to situations in which scientists in two or more disciplines coordinate their research programs so as to investigate a particular issue or phenomenon with the tools and ideas of each of the disciplines. The existence of convergent relations signals the presence of a true interdisciplinary enterprise. In what follows, we discuss the kind of relations that have historically existed between cognitive and neuroscientific approaches to each of the three memory issues, and consider the extent to which convergent relations have begun to develop.

\section{CONSOLIDATION}

The notion that memories become permanently fixed, or consolidated, only some time after registration of a stimulus or event, is a familiar construct in memory research. Although a consolidation stage is a generally, though not universally, accepted part of the memory formation process, exactly what is meant by the term consolidation remains largely unspecified after nearly 100 years of research-so much so that Crowder (1989) recently referred to the term as "bankrupt." For example, consolidation can be used in a physiological sense to refer to neural activation or reverberation following presentation of a stimulus (e.g., Müller \& Pilzecker, 1900; Burnham, 1903; DeCamp, 1915; Hebb, 1949), or in a psychological sense to refer to more abstract processes occurring during the same, or a more extended, period of time (e.g., Burnham, 1903; Bartlett, 1932; Squire, Cohen, \& Nadel, 1984). At another level, confusion exists over whether consolidation is better viewed as an active or a passive process: in both cases the result is the formation of a potentially permanent memory, yet there are important differences between models of consolidation that depict it as resulting from automatic mechanisms and those that depict it as requiring effort and organization. Yet another area of debate concerns the duration of the consolidation process. Estimations of the time required for consolidation to conclude have varied from several seconds to years. These issues have framed the nature of consolidation research for the past 100 years, and serve as the focus for the present review.

\section{Historical Overview}

Although analogies for memory have been around at least since the ancient Greeks (e.g., Plato's notion of etchings in a tablet of wax), the explicit identification of the notion that it might take time for a process to create permanent memories is relatively new. Quintillian, in his treatise Institutio Oratoria (On the Education of the Orator), seems to be the first person to make reference to such a process of fixation or consolidation. In reflecting on how the interval of one night can greatly increase the strength of memory, he referred to "a process of ripening and maturing" (Herrmann \& Chaffin, 1988, p. 103). Other than this passing mention of the possibility that the strength of a memory can increase over time, we have been unable to find evidence that the concept of consolidation was considered until the late nineteenth century.

\section{Early Psychological Investigations and Pbysiological Speculations}

Müller and Pilzecker (1900) are usually cited as the primary reference to consolidation. Although they may have been the first to use the term "consolidation," hypotheses about such a concept based on clinical evidence predate their work by about 20 years. Ribot $(1882,1892)$, for instance, invoked the notion of consolidation to explain brief periods of retrograde amnesia, finding that when recovering from unconsciousness, a patient "lost not only the recollection of the accident . . . but also the recollection of a more or less long period of his life before the accident" (1892, p. 779). He cited 26 cases of retrograde amnesia that were first reported by Dr. Frank Hamilton. In these early anecdotal accounts, the amnesia was thought to be very short, affecting memory for events in the minutes preceding the trauma. Ribot concluded that "in order that a recollection may organize and fix itself, a certain time is necessary, which in consequence of the cerebral excitement [in the case of trauma] does not suffice" (Ribot, 1892, p. 799).

Müller and Pilzecker (1900) extended the notion of consolidation beyond previous anecdotal and clinical accounts by conducting a series of experiments in which they manipulated subjects' activity between study and test. They observed that memory performance was related to the nature of interpolated activity. For example, a task of describing a landscape picture between studying nonsense syllables and a subsequent memory test produced poorer memory performance than a condition 
with no intervening task. Based on these results, they concluded that a "physiological activity persists for some minutes in the nervous tracts concerned, and that this ... increases the fixity of the associations" (cited in McDougall, 1901, p. 393). McDougall saw the connection between this finding and Ribot's work, suggesting that it "throws light upon, we might almost say explains, certain recorded cases in which a severe blow on the head has wiped out completely the memory of immediately preceding events. It throws light too on the fact, noted by some persons, that what is learnt immediately before falling asleep is often remembered with exceptional accuracy" (p. 393). A return, it appears, to Quintillian's original example. It is interesting to note that this very hypothesis became the subject of direct experimental investigation aimed at distinguishing between theories of decay and interference in explaining forgetting (e.g., Jenkins \& Dallenbach, 1924).

In this early experimental phase, Burnham (1903) provided the most detailed consideration of consolidation. Unlike Müller and Pilzecker, he discussed consolidation not only in terms of hypothetical physiological activity, but also with respect to psychological processes of organization and association:

In normal memory a process of organization is continually going on, a physical process of organization and a psychological process of repetition and association. In order that ideas may become part of permanent memory, time must elapse for these processes of organization to be completed. (p. 132)

Burnham based his theory primarily on evidence from cases of retrograde amnesia that, like Ribot, he viewed as evidence for a consolidation deficit: "The essential characteristic of these cases of retroactive amnesia is that the memory is lost because it was never fully organized" (p. 129). Foreshadowing future consideration of the "active-passive" theme, he suggested that the consolidation process is not merely one of repetition, but that it also includes the formation of associations that depend on "physiological processes" that are extended in time Burnham acknowledged that his theory was similar to that of Ribot, and also acknowledged the contribution of Ebbinghaus (1885/1964) to his thoughts on the role that time plays in processes of organization. When learning nonsense syllables, Ebbinghaus found that massed practice was less effective than spaced practice. Burnham took this as evidence that "there must be time for nature to do her part" (p. 131).

At about the same time that Burnham published his work, independent (and more general) physiological research into the nature of nerve excitations was being conducted by Sherrington (1906). His primary interest was in the possibility of afterdischarge in nerve cells, particularly in the spinal cord. Although this research does not appear to have been conducted with questions of memory or consolidation in mind, it did provide an early model for, and apparent confirmation of, the speculations of such researchers as Müller and Pilzecker and Burnham-namely, that excitations in the nervous system could continue after the stimulus ceased to exist.

All of the early researchers speculated about a physiological mechanism underlying the process of consolidation. DeCamp (1915), however, presented what Glickman (1961) later described as "probably the most detailed piece of pseudoneurological speculation" (p. 218):

From the neurological standpoint, in the learning of a series of syllables, we may assume that a certain group of synapses, nerve-cells, nerve paths, centres, etc., are involved. Immediately after the learning process that after-discharge continues for a short time, tending to set the associations between the just learned syllables. Any mental activity engaged in during this after-discharge, involving or partially involving the same neurological group, tends, more or less, to block the after-discharge, and gives rise to retroactive inhibition. Engagement in any mental activity involving a new-so far as it is new-group of synapses, neurones, etc., would allow the setting process of the just excited group to proceed unhindered. The effect of retroactive inhibition would vary directly as the relative identity of the neurological groups concerned. (p. 62)

Despite the speculative nature of this account, it is remarkably similar in some respects to the cell-assembly theory that Hebb (1949) produced 30 years later.

A review of prominent psychology texts of the 1920s (e.g., Pieron, 1929; Woodworth, 1929) reveals that consolidation was already considered to be an integral part of the memory process. The sources of evidence cited as supporting the phenomenon included (1) so-called "shock amnesia," where retrograde effects suggested that the shock interfered with a consolidation-like process; (2) retroactive interference, in which the nature of the interpolated task, and its difficulty, suggested that some part of the mnemonic process continues after the stimulus is terminated; and (3) perseveration (or spontaneous recollection) of recently encountered material, especially of materials that were learned during interrupted activity (e.g., Zeigarnik effect), attested to the continuation of central activity after stimulus cessation. Notwithstanding this catalog, there remained a healthy skepticism about the reality of consolidation, as exemplified by Lashley's view that consolidation "can be explained equally well by other hypotheses" (Lashley, 1918, p. 363) and Woodworth's suggestion that "the evidence for a consolidation process following active learning is rather scrappy and inconclusive" (Woodworth, 1929, p. 92).

From this promising beginning, research into processes of consolidation was overshadowed by studies of retroactive interference and the movement toward be- 
haviorism that were popularized in the 1930s. Interference paradigms (e.g., McGeogh, 1932) focused on how "memory strength" could be measured by, or was related to, the degree of interference between study and test. At the same time, with the widespread acceptance of behaviorism, most psychologists belittled the importance of explanations based on physiological activity in the analysis of psychological processes, including memory. These historical developments no doubt contributed to the end of the early phase of thinking about consolidation and led to a brief dormant period for consolidation research.

\section{Early Experimental Studies}

This dormant period persisted for only about 10 years, until Zubin and Barrera (1941) presented the first experimental studies of the impact of brain stimulation on consolidation. They observed the effect of electroconvulsive shock (ECS) on paired associate learning, and reported that the impact of ECS depended on the interval between learning and the disruptive brain stimulation. More specifically, the briefer the interval between learning and ECS, the more adverse its effect on memory performance. This finding paralleled that observed in naturally occurring retrograde amnesia. Therefore, the ECS procedure seemed to provide an experimental method that could interrupt the consolidation process in a controlled fashion.

Although their study had been conducted in humans, Zubin and Barerra's research aroused the interest of animal psychologists by apparently providing a viable method for systematic investigation of consolidation. For the next 30 years, researchers concentrated their efforts on two fundamental aspects of the consolidation process: (1) how long it takes fixation to occur, and (2) what kinds of neurophysiological processes are critical to its successful conclusion. In what follows we focus on the former question; any analysis of the latter would take us far afield and demand attention to such detailed matters as protein synthesis, macromolecules, DC potentials, and more. Though fascinating, this pursuit is beyond the scope of the present article.

Duncan (1949) conducted the first study into the effects of ECS on memory consolidation in laboratory animals. He trained rats to associate the appearance of a light with a shock to the feet, and administered ECS to different groups of rats at various times following each learning trial, using intervals ranging from $20 \mathrm{sec}$ to 14 hr. Duncan reported a clear pattern of impairment that was associated with the length of the interval between the conditioning trial (training) and the ECS: the sooner ECS was administered after the light-shock pairing, the more it appeared to inhibit the ability of the rat to form an association between the light and the shock. The inhibitory effect of the ECS occurred so long as it was administered within $60 \mathrm{~min}$ of the learning trial, suggesting that consolidation lasted for up to $1 \mathrm{hr}$.

However, Miller and Coons (1955) provided another interpretation of the same result. They argued that the observed behavioral effects of ECS could have been produced, not by disruption of a consolidation process, but rather by the creation of fear in the experimental animals. Coons and Miller (1960) compared the consolidation and conflict interpretations of ECS effects by arranging an experiment in which amnestic and fear-related effects would oppose each other rather than summate, as was the case in Duncan's original experiment. This was accomplished by using a "passive" rather than an "active" avoidance design. That is, the rat's task involved not making a particular response, thereby producing a situation in which fear, and the "freezing" typically elicited by it, would be likely to improve rather than hinder performance. Coons and Miller observed that learning of this passive avoidance task was faster when ECS closely followed each trial, and concluded that "while these results do not disprove the occurrence of retrograde amnesia, they cast serious doubts on the conclusions of previous studies purporting to prove its occurrence" (Coons \& Miller, 1960, p. 531). In retrospect, the lasting contribution of this study may have been its use of the passive avoidance paradigm, which both controlled for the possibility that ECS was having its effects through fear conditioning, and provided a learning task of sufficient simplicity that animals could learn it in one or at most a few trials. Much subsequent research on consolidation came to rely on such tasks, which enabled researchers to determine with some certainty exactly when learning occurred, and hence when the memory consolidation process could be said to have started.

In an independent line of enquiry, not actually directed at the question of consolidation, Brady and Hunt (1951; Hunt \& Brady, 1951) tested the effect of ECS on learning of a conditioned emotional response (CER) in rats. This task, first reported by Estes and Skinner (1941), involved pairing a stimulus such as a tone or a light, with a shock delivered to the water spout from which the animal drank. The CER was observed as a significant decrease in contacts with the water spout during presentation of the tone or light CS. In early experiments Brady and Hunt observed that ECS could reduce or eliminate previously conditioned emotional responses. However, subsequent experiments (Brady, 1951) showed that ECS did not actually obliterate the CER because it could "spontaneously" reappear within 30 days of the ECS treatment. Brady (1952) then showed that conditioned emotional responses could survive ECS treatments that were delayed by more than 30 days. Taking these results together, Brady concluded that "the conditioned emotional response increases in strength with elapsed time and that this increase in strength (or, perhaps, change in quality) may be sufficient to obscure the effects which ECS has upon the response" (Brady, 1952, p. 13). This hypothesis 
clearly reflects the operation of a consolidation mechanism.

Experiments that attempted to identify a time course of the consolidation process were not limited to the use of ECS to interrupt memory processes (see Lewis, 1969). Other methods included using anoxia (e.g., Hayes, 1953; Ransmeier \& Gerard, 1954; Thompson \& Pryer, 1956), anesthesia (e.g., Leukel, 1957), temperature changes (Gerard, 1955), and brain stimulation (e.g, Glickman, 1958; Thompson, 1958). These different methods, much like ECS itself, produced quite inconsistent results. As a consequence, by the 1970 s the idea that consolidation entailed a simple fixation process was no longer tenable. The time course for consolidation appeared to be quite different from study to study (Chorover, 1976), and perhaps even experiment specific (McGaugh \& Gold, 1976). As a result of the variability in the time course of the consolidation process, McGaugh and Gold (1976) argued that "RA [retrograde amnesia] gradients do not provide a direct measure of the time required for the consolidation of long-term memory" (p. 550), and furthermore suggested that "memory disruption studies provide direct information only about the susceptibility of memory to disruption; they do not provide direct information about the underlying memory processes" (McGaugh \& Gold, 1976, p. 551; see also Weiskrantz, 1966; McGaugh \& Dawson, 1971; Gold \& McGaugh, 1975).

Much of the aforementioned research, aimed at determining the duration of a time-dependent consolidation process, was strongly influenced by Hebb's theoretical ideas. He argued for a dual-trace memory process at the physiological level: a transient trace is first established, which then undergoes some structural modification in order to become more permanent. According to Hebb "the persistence or repetition of a reverberatory activity (or "trace") tends to induce lasting cellular changes that add to its stability" (Hebb, 1949, p. 62). Note that in Hebb's formulation the transient trace is located in the same ensemble of neurons as the permanent trace; in deed, it was precisely the reverberation underlying the transient trace that provided the repeated activations leading to the permanent, structural, modifications. This structural modification was quite similar to the early concepts of consolidation posited by Ribot, Müller, and Pilzecker, Burnham, and DeCamp. Despite the obvious similarity to these earlier speculations (see previous section), Hebb (1949) seemed unaware of his predecessors, as he failed to cite any of the early researchers in his well-known monograph.

Though this era was dominated by physiologically oriented studies of consolidation, there was one prominent addition to the paradigms available for studying consolidation at the psychological level-the Brown-Peterson short-term memory task (Brown, 1958; Peterson \& Peterson, 1959). In this task subjects are presented with a string of three or four letters or numbers, and are then asked to repeat them after a retention interval ranging from 0 to $60 \mathrm{sec}$. Rehearsal of the to-be-remembered information is inhibited by having the subjects perform any one of a number of arithmetic operations. Although Peterson and Peterson (1959) failed to make any reference to consolidation or the consolidation literature, Brown (1958) delineated a link between these short-term memory experiments and the process of consolidation. In particular, he suggested "that the lability of the memory trace-at least to gross cerebral disturbance--is highest immediately after learning and declines rapidly with age", citing the ECS work of Duncan (1949) as evidence (Brown, 1958, p. 18). His experiments on short-term memory confirmed that memory traces are most fragile immediately after they are formed by showing rapid forgetting over time.

\section{Recent Research}

The skepticism inherent in the literature reviews during the 1970 s (e.g., Chorover, 1976; Gold \& McGaugh, 1976) led to another change in how the process of consolidation was investigated. If the traditional types of disruption experiments could not shed light on the duration of consolidation, and if Hebb's theoretical formulation regarding short-term reverberation could not account for lengthy consolidation effects, it was unclear how to proceed. At about this time, however, neuropsychological studies began to address the consolidation issue. These studies focused on the locus of memory failure in amnesic patients-that is, whether the deficit could be attributed to a storage or a retrieval problem. For example, Milner (1965) suggested that the anterograde amnesia observed in the classic patient HM could be attributed to a consolidation deficit: adequate short-term traces are not transformed into permanent traces (e.g., Hebb, 1949). By contrast, Warrington and Weiskrantz (1968, 1970) sought to explain the same facts of organic amnesia in a quite different way, as a defect in retrieval processes rather than in consolidation/storage mechanisms. Satisfactory resolution of this debate has yet to occur (for discussion, see Miller \& Springer, 1973; Miller \& Marlin, 1984; Wickelgren, 1979; Squire, 1980) because of inherent difficulties in isolating the various stages in the memory process (e.g., Watkins, 1978). As a result, the data regarding anterograde amnesia remain ambiguous with respect to the construct of consolidation.

The neuropsychological literature has also addressed the issue of "long-term" consolidation in studies of retrograde amnesia. In these studies, the question concerns whether or not there is a temporal gradient to the retrograde amnesia observed in brain injured patients of the kind initially discussed by Ribot (1882). To the extent that there is an identifiable gradient with more recent memories selectively impaired, there is evidence for a consolidation process that lasts considerably longer than the minutes envisioned by Ribot and Burnham. Initially, 
Sanders and Warrington (1971) suggested that there is no gradient to retrograde amnesia because they observed that premorbid events are equally likely to be recalled regardless of the time period from which the events were selected. However, Marslen-Wilson and Teuber (1975) found evidence for a relative preservation of older memories in the amnesic patient HM, and Seltzer and Benson (1974) and Albert, Butters, and Levin (1979) reported temporal gradients in Korsakoff patients. Several authors have attempted to reconcile these disparate findings in terms of methodological factors such as ceiling/floor effects and saliency of items (Squire, 1987; McCarthy \& Warrington, 1990).

A series of studies conducted by Squire and colleagues has attempted to document a gradient in retrograde amnesia as evidence for a long-term consolidation process. For example, it was observed that electroconvulsive therapy (ECT) administered to psychiatric patients caused a retrograde amnesia for information learned for up to 3 years prior to the treatment (Squire, Slater, \& Chace, 1975; Squire \& Cohen, 1979). Although shorter temporal gradients had been observed in most animal studies (see previous section), using four spaced electroconvulsive shocks in mice, Squire and Spanis (1984) produced amnesia for up to 3 weeks prior to the shock treatments.

The idea that events occurring after initial registration of a stimulus contribute to the ultimate outcome of the consolidation process formed part of the consolidation model proposed by Squire et al. (1984). These authors supposed that information is first represented in those temporal lobe structures, primarily the hippocampus, that are disrupted in organic amnesia. Over a fairly extended period of time, whose duration depends on intervening events that contribute to what can be viewed as "rehearsal," this information or some subset of it is established in brain circuits outside the hippocampus (presumably in neocortex). After some time period this extrahippocampal memory storage system becomes capable of supporting information retrieval on its own, and the active involvement of the hippocampal system is no longer required. This model has the virtue that it accounts for the existence of fairly lengthy consolidation processes, explains the subtle role of the hippocampal system, and seems consistent with both cognitive and neural accounts of consolidation.

Although most of the recent research pertinent to this hypothesis has come from neuropsychological studies of human amnesia, research involving nonhuman primates has also provided some relevant evidence. Seeking evidence for retrograde amnesia in an experimental setting with monkeys, Dean and Weiskrantz (1974) trained animals on a set of visual object discriminations at varied times prior to making lesions in area TE, a part of the neocortex known to be essential for complex visual learning. They found no evidence for a gradient of retrograde amnesia over the 4-week period.
Using the methods first employed by Dean and Weiskrantz (1974), Salmon, Zola-Morgan, and Squire (1987) sought evidence for a retrograde amnesia gradient after extensive lesions in the medial temporal region, including hippocampus and amygdala. They too failed to find evidence for the kind of gradient that would demonstrate the existence of a consolidation process. However, ZolaMorgan and Squire (1990) have recently reported a study in monkeys with lesions limited to the hippocampus, which supports the model of temporally graded retrograde amnesia. Intact animals were taught 100 object discrimination problems over a 16-week period, such that 20 different problems were acquired at two-weekly intervals. Then, hippocampal excisions were performed, and memory was tested by examining retention of all the discriminations. Control monkeys performed quite well on those object discriminations learned within the past 8 weeks, and were still above chance on those learned 12 and 16 weeks prior to the surgery. Monkeys with hippocampal excisions were well below normal on the object discriminations learned up to 8 weeks prior to surgery, but seemed quite normal on those learned 12 or 16 weeks earlier. They argued from these results that for at least an 8-week period after acquisition of an object discrimination, normal memory performance requires that information be accessed from hippocampus; beyond that time consolidation has proceeded far enough in neocortex that removal of the hippocampus does not prevent normal retention. Similar results have also been reported in rats tested on two different types of memory tasks (Kubie, Dayyani, Muller, Cohen, Major, \& Sutherland, 1990; Winocur, 1990). Once again, different tasks generated different estimates of the length of the consolidation period.

\section{Summary}

The earliest efforts in consolidation research involved psychologists or medical scientists trying to explain the phenomena of retroactive interference and retrograde amnesia. There is no evidence of physiologically oriented research directed at issues of memory consolidation during this period, perhaps reflecting the lack of tools available to explore memory at this level. However, psychologists did not avoid discussions of the brain, and the relation between mental and physiological processes. Not only did they consider underlying physiological events, but they also produced detailed speculations about what the underlying mechanisms of the psychological processes might be (e.g., Burnham, 1903; DeCamp, 1915). The fact that psychologists made use of physiological observations in their formulations indicates a form of what we have labeled complementary relations between the two approaches. 
This early stage was followed by a period during which psychologists and physiologists paid only lip service to each other's perspective with respect to memory processes in general, and consolidation in particular. For example, the physiologist Konorski (1948) believed that "whereas in psychology experimental research into memory is regarded as very important, and constitutes one of the best explored departments of this science, physiology so far has had little to say on the subject. One gets the impression that physiologists have even avoided raising clear issues in this field" (p. 85). By contrast, Stellar (1957) argued that "psychologists have . . . not been able to develop concepts of attention, intelligence, and even learning and memory that are satisfactory for physiological analysis." Finally, toward the end of this era Melton (1963) suggested that "memory has never enjoyed even a small fraction of the interdisciplinary interest that has been expressed in symposia, discoveries, and methodological innovations during the last five years" (p. 1). Clearly cognitive and neuroscientific research agendas had little in common at this time-an example of what we have referred to as collateral relations between the two fields.

Cognitive psychology has had little to say about consolidation during the past 25 years. Nearly all of the relevant research has been conducted in the context of investigations of reminiscence (Ballard, 1913; Buxton, 1943), hypermnesia (see Payne, 1987 for a review). Reminiscence refers to the possibility that memory strength can spontaneously increase over time, as evidenced by remembering previously forgotten information without the benefit of additional learning trials. As such, it would appear to suggest that consolidation continues long after learning. However, Roediger and Payne (1982) observed that reminiscence was a function of practice effects associated with repeated testing, and not merely a function of the passage of time alone.

Although cognitive psychology itself has not contributed directly to recent research on consolidation, the past few years have witnessed a trend toward convergent relations between neuropsychological analyses of amnesic patients and psychobiological studies of animals. Although the level of neuroscientific analysis is still fairly gross (e.g., in terms of regions of the brain involved, as opposed to the nature of cellular changes), the research of Squire and colleagues, for example, has attempted to attack the consolidation issue with tools and ideas from both psychological and physiological levels of analysis, and in doing so has achieved a degree of convergence between the levels. It seems likely that further interdisciplinary research will be necessary if consolidation is to become an operationally defined, and theoretically understood, aspect of memory. Clearly, neurophysiological events are going to underlie the observed behavior changes manifested as a result of consolidation. But this does not mean that the behavioral events are any less important: neuroscientific research must necessarily consider cognitive phenomena if it is to answer all the interesting questions about consolidation.

\section{THE NATURE OF MEMORY REPRESENTATIONS}

A fundamental issue throughout the history of memory research concerns the psychological and physiological properties of changes in the mind/brain that preserve information over time-that is, the nature of the "memory trace" or "engram." We refer to this issue as the problem of memory representation. Whereas studies of consolidation focus on the temporal properties of memory storage, research and theorizing about memory representations attempt to specify the manner in which information is stored. As we shall see, for more than 100 years, the problem of memory representation has been intimately intertwined with the question of whether memories are represented in a localized or distributed fashion. Although the problem of memory representation involves issues other than localized vs. distributed storage, and issues pertaining to localization involve processes other than memory, the two problems show a high degree of historical overlap. The main question at hand concerns the nature of the relation between psychological and physiological approaches to the general problem of memory representation, which has most frequently taken the form of a debate about localized vs. distributed storage.

The issue of localized vs. distributed representations in memory has been debated at two levels. First, there is the macro level of analysis, which is concerned with where memories are represented. There are two general possibilities here: either one or several regions of the brain are responsible for storing all sorts of memories, or memories are scattered throughout the brain. The second level of analysis is the micro level, which is concerned with bow each memory is represented, regardless of where memories (as a group) are stored. Once again there are two possibilities: either there are one-to-one mappings of memories to one or a few nerve cells, or memories are distributed in networks throughout the brain (or region of the brain responsible for memory). Although the focus of the present section will be the micro-level question of how individual memories are represented, we begin with a discussion of the pre cursors to this debate in the form of the macro-level issue of where memory is represented.

\section{Historical Overview \\ Early Physiological Speculations}

The idea that the storage of memory might be confined to a specific area of the brain can be traced to phrenology and its attempts to localize cerebral function in general. 
Gall (1835) and Spurzheim (1834) argued that different areas of the brain are responsible for different mental faculties (e.g. memory), and that the contours of the skull reflect the relative strengths of these various faculties in each individual. Although this extrapolation from the shape of the skull to underlying mental strengths and weakness was wildly inaccurate, the basic idea of cerebral localization of function has survived as an essential part of modern day neuropsychology. Most nineteenth-century researchers, including Broca (1861), Wernicke (1874), and Munk (1881), favored a localizationist perspective on cerebral functions, including memory.

However, there were a few individuals who objected to this localizationist position, favoring instead the view that functional capacities are widely distributed in the brain. Flourens (1824) presented evidence for this perspective when he removed parts of the forebrain of various animals and observed that the subsequent changes of behavior did not depend on the precise part removed. This observation suggested to him that psychological functions are not localized in separate parts of the brain, and that behavioral changes after brain lesions are related to the size, rather than the location, of the ablation. With respect to memory function in particular, Kussmaul (1877) rejected the notion that memory has a "special storehouse in the brain where images and ideas lie together arranged in separate compartments" (cited in Gomulicki, 1953, p. 11).

Although the debate at this macro level was never fully resolved, a shift in emphasis toward the micro-level issue of how individual memories are represented occurred in the late nineteenth century. This shift seemed to result from a conflation between the two levels of the localized vs. distributed representation debate. For example, the philosopher Alexander Bain rejected the notion of a "cerebral closet" of memories. With this statement, he seemed to be rejecting the localizationist perspective at the macro level, suggesting that memories do not reside in one particular place. However, when he suggested that "for every act of memory . . there is a specific grouping or co-ordination of sensations and movements, by virtue of specific growths in the cell-junctions" (cited in Gomulicki, 1953, p. 8), he was speculating at the micro level of analysis about how an individual memory is represented.

Further speculations regarding the physiological nature of memory representations came from sources such as James (1890), Freud (1895; in Bonaparte et al., 1954), Loeb (1901/1973), and Semon (1904/21), each of whom will be considered in turn. In his landmark book Principles of Psychology, William James (1890) presented a rather conservative summary of early views on memory representations, arguing for an underlying physiological mechanism, but acknowledging that little was known about it: "These habit-worn paths of association are a clear rendering of what authors mean by 'predisposi- tions', 'vestiges', 'traces', etc. left in the brain by past experience. Most writers leave the nature of these vestiges vague; few think of explicitly assimilating them to channels of association" (James, 1890, p. 655-656).

A far more detailed speculation about the nature of the physiology underlying memory representations was offered by Sigmund Freud in his prepsychoanalytic writing, "Project for a Scientific Psychology" (published posthumously in Bonaparte et al., 1954). Freud identified the apparently contradictory requirement that neurons receive and discharge impulses, but also retain some level of excitation. As a result, he posited two types of neurons: "There are permeable neurones which serve the function of perception, and impermeable neurones which are the vehicles of memory and presumably, therefore, of psychical processes in general" (Bonaparte et al., 1954, p. 360). He believed that "memory is represented by the differences in the facilitations between the impermeable neurones" (Bonaparte et al., 1954, p. 361). Freud, then, argued for a strict localization of memory function with a one-to-one mapping between a specific memory and specific neuronal facilitation. However, 20 years later he recanted by acknowledging that "every attempt to deduce from the facts a localization of mental processes, every endeavour to think of ideas as stored up in nerve-cells and of excitations as travelling along nerve-fibres, has completely miscarried" (Bonaparte et al., 1954, p. 350).

Jacques Loeb, a pioneer in experimental biology who tried to explain mental processes in terms of fundamental "tropisms," presented further, apparently independent, speculations about the micro-level issue of memory representations. He began his research as a student of Munk (who had performed well-known experiments on "mind blindness" in dogs), and early in his career believed "that visual images of memory are localized in isolated cells or groups of cells" (Loeb, 1901, p. 277). However, his own work later forced him to conclude that Munk was incorrect, leading him instead to present a detailed account of the need for distributed representations of memory:

It is my opinion that these histological or corpuscular hypotheses of the images of memory must be supplanted by dynamical conceptions. The dynamics of the process of association is the true problem of brain-physiology. Even if the hypotheses of psychic localization were not contradicated by all the facts, to point out the centres would not be a solution of the dynamical problem. By merely showing a student the location of a power-plant, we do not explain to him the dynamics of electric motors. (p. 278)

Loeb, then, presents a compelling logical argument for the need to pursue a micro-level analysis of memory representations. His suggestion refers to the dynamics of this representation, whereas we have focused on the static structural nature of the representation. 
Richard Semon, a German biologist who wrote two books on memory just after the turn of the century that are still unfamiliar to most contemporary students of memory (see Schacter, 1982), is probably most well known for coining the term "engram." In discussing the engram, or memory trace, Semon considered both the micro and macro levels of analysis that we have identified in this paper. In doing so, he pointed out that discussions of localized and distributed function need not be mutually exclusive, so long as separate levels of analysis are considered:

We seem, therefore, to be placed in the dilemma of having either to reject altogether a localisation theory which imagines that each single engram can be stored up in a cerebral cell-or in a comparatively small complex of cerebral cells-as in a separate drawer, or to admit that in the human organism a special interdependence exists between definite regions of the cerebral cortex and the ecphory, or, as perhaps we ought to say, the possibility of ecphory of distinct individually - acquired engrams. The latter admission implies, however, the recognition of a certain localisation, although it need not be the kind which makes each nerve-cell of the brain a repository for a specific engram. (pp. 119-120).

Here, Semon explicitly allowed for the possibility of macro-level localization of memory function while rejecting the idea of micro-level localization of individual engrams. Semon (1909/1923) also put forward ideas concerning the nature of the engram at a psychological level of analysis. He argued that engrams are composed of specific features or components that represent different aspects of an experience, and that the various components of an engram are linked together by processes operating during retrieval (see Schacter, 1982 for further review).

It is worth noting that although our discussion of the early literature has focused on theorists who posited physiological bases for memory representations, not all writers of this period believed that memories are represented in a physical form. For example, McDougall (1911) and Bergson (1911) both maintained that memory can be discussed only in terms of a nonmaterial, "psychical" field. Not surprisingly, the speculations of these and other dualists were neither cited nor further developed by subsequent memory theorists. Unfortunately, the ideas of Loeb and Semon suffered the same fate, despite their clear relevance to contemporary concerns.

\section{From Lasbley to Hebb}

Karl Lashley is among the best-known researchers into issues about memory representation. His work involved a return to the macro level of analysis, as it was directed toward identifying where memories are stored in the brain. In a long series of experiments he systematically varied the location and extent of cortical lesions, and then tested the effects of such ablations on memory (and other cognitive functions). He found support for the law of mass action, which supposed that the impact of a brain ablation depends on the size, rather than the site, of the damage (similar to Flourens). These results led Lashley (1950) to conclude that memory is not simply composed of an isolated representation, but rather that multiple representations of a single event are formed, and that memory must be highly associative in nature. Most relevant to the question of distributed vs. localized representations, he was forced to accept that memory is distributed throughout the brain. Lashley's conclusion, however, was based on his inability to isolate any one part of the brain as responsible for memory function, but as Zangwill (1963) pointed out, his results do not necessarily eliminate the possibility of localized function. Thus, Lashley's idea that there was some equipotentiality of function could be applied within specialized (e.g., localized) areas of the cortex. This position has since been incorporated in the recently developed "parallel distributed processing" (PDP) models (see below).

At about the same time, Gestalt psychologists also addressed the issue of memory representations. They argued for an isomorphic relation between the psychological and physiological processes of representation. For example, Köhler (1947) suggested that "All sound theories of memory, of habit, and so forth, must contain hypotheses about memory traces as physiological facts. Such theories must also assume that the characteristics of traces are more or less akin to those of the processes by which they have been established" (p. 252). These statements, however, remain relatively neutral with respect to the issues of where or how the traces are represented. Koffka (1935), however, did consider the macro-level question of where memory is represented. He argued that Lashley's results provided proof that "no trace has an independent function, nor even an independent existence" (p. 454). Citing Lashley's work again, he posited a distributed representation: "When Lashley says that maze habits are not localized he does not mean that learning leaves no after-effect, i.e., no traces whatsoever. It is perfectly compatible with his results that for maze habits these traces are distributed over the entire cortex" (p. 454). Other Gestaltists, however, took Lashley's results to the extreme and suggested that the entire concept of a memory trace, and therefore presumably of representations in memory, was incorrect. For instance, Wheeler and Perkins (1932) argued that "the brain, therefore, is not a mass of structures each having its own particular and independent functions. In face of these facts the trace theory is inconceivable" (p. 387).

Although Gestalt psychologists clearly considered both psychological and physiological aspects of memory representations, critics contended that they were not en- 
gaged in a truly interdisciplinary endeavor. As Gomulicki (1953) points out,

Gestaltists freely propound physiological hypotheses on the basis of their psychological evidence-sometimes with a cavalier disregard for neurological facts-but they have never been known to modify any of their psychological views as a result of physiological discoveries! (pp. 41-42)

D.O. Hebb (1949) picked up where his mentor Lashley left off. Hebb was convinced that the phenomena unearthed by Gestalt psychologists demonstrated that memory representations had to embody some "dynamic" aspect. However, as a neuropsychologist he did not accept Lashley's pessimistic conclusion that engrams could not be localized in the brain. His solution to this dilemma has already been noted in the consolidation section of this paper: memories are represented in distributed collections of nerve cells known as cell assemblies. Because these assemblies are distributed, and because they can be activated through diverse entry points, damage in various parts of the brain should have little effect on particular memories. It is only when extremely large ablations are made that one might expect to observe memory loss; Lashley's Law of Mass Action, therefore, can be accounted for within this approach. Hebb also proposed mechanisms by which memories are formed at the neuronal level: correlated activity between presynaptic and postsynaptic elements led to increased synaptic efficacy in the future. This mechanism, lately referred to as Hebb's Law, has been included in many recent learning theories, and has gathered considerable empirical support. At the time Hebb proposed his cell assembly theory, and its solution to both the macro- and microlevel issues of memory representation, there was no way to assess his ideas.

In this era of physiologically oriented hypotheses about the nature of memory representation, Bartlett (1932) presented a purely psychological hypothesis. He proposed extending the concept of the "schema," originally proposed by Head and Holmes (1912), to memory. The concept of a schema, or continually evolving ammalgamation of memory traces, was developed with reference to the question of postural recognition (Head \& Holmes, 1912). Bartlett used the concept of schema to account for the "reconstruction" in memory that he observed in several experiments (Bartlett, 1932). For example, in repeated testing of memory for a simple story, Bartlett observed that although subjects provided the same theme of the story over recall trials, the manner of expression and details reported differed. Because the concept of a schema entails a rejection of the notion that specific memories map onto individual traces, Bartlett could be viewed as a proponent of distributed representations of memory at the micro level. However, he failed to provide any indication of what a schema is in physiological terms, or how it might operate.

\section{The Modern Era}

In a sense the modern era of research on memory representations can be said to have been ushered in by Gomulicki's comprehensive review of ideas about the memory trace in 1953. In his paper, Gomulicki identified several reasons why the puzzle of memory remained unsolved, one of which was "the comparative lack of cross-fertilization of the relevant sciences" and the consequent absence of a "recognized science of 'mnemology' (covering all aspects of the memory problem) on which one can specialize" (Gomulicki, 1953, p. 65). However, it took several years before his call for interdisciplinary research was heeded.

Before interdisciplinary approaches began to evolve, several new lines of investigation were developed. For example, Van Heerden (1963) added to the independent sources of theories about the nature of memory representations by relating memory to the newly conceived notion of holography. Van Heerden argued that the threedimensional information storage properties of holographic images are a suitable model for associative memories. Although not expounding at length on a theory of memory storage, he did suggest that there are two different regions for storage-one "where all information of a passed experience is mixed to make fast search and recognition possible; and a second region where the information about different situations is stored separately" (Van Heerden, 1963, p. 399). Although a few formal cognitive models of memory have incorporated some of the basic ideas of the holographic metaphor (e.g., Pribram, 1971; Eich, 1982; Murdock, 1982), Van Heerden's theory has been for the most part overlooked in the psychological literature.

Another independent line of inquiry came with the emergence of cognitive psychology in the late 1960s. Cognitive psychologists addressed the issue of representations in memory in purely psychological terms, viewing underlying physiology as an unnecessary complication. So, for instance, Tulving and Bower (1974) claimed that

the past history of theories about the memory trace (see Gomulicki, 1953) contains many hypotheses that have been unprofitably tied to further guesses about the neurological mechanisms involved; and the functional hypothesis is discredited when the postulated neurology is proven incorrect, inadequate, or naive. (p. 231)

Rather than focusing on the nature of neuronal interactions, then, cognitive psychologists proposed models of memory based on "features" or "attributes" of the memory trace (Bower, 1967; Underwood, 1969; Tulving \& Bower 1974). For example, Tulving and Bower (1974) defined a memory trace as 
the pattern of performances, observed under systematically varied retrieval conditions, that provides a description of what a given trace does. The trace thus becomes a hypothetical construct we use to pull together this large list of relations between different questions directed at the system and the output from the system. (p. 294)

These models consider only the micro level of analysis. Underwood (1969) acknowledged the limitation of these types of theories when he suggested that an individual trace can be viewed in terms of its attributes (e.g., temporal, spatial, modality), but that such a conception is "not compatible with statements about memory traces as long as the plural is emphasized" (p. 571).

For much of the 1970 s, research on the nature of memory representations proceeded along quite separate lines in neural and cognitive science. Neuroscientists focused on two issues: the cellular mechanisms underlying memory formation, and the regional localization of memory storage for specific types of learning. This latter enterprise reflected the general acceptance by most neuroscientists that there is no single memory organ, and that memories for different kinds of information are likely to be stored in quite different brain regions. Thus, the search for the engram became the search for any engram (see Thomson, 1976). It is an unresolved empirical matter as to whether engrams located in different brain regions are formed by the same underlying molecular mechanisms. As we noted above, much recent attention has focused on the potential neural instantiation of Hebb's synaptic principles; there is considerable evidence that long-term potentiation, discovered by Lømo (1966), and further explored by Bliss and Lømo (1973) and Bliss and Gardner-Medwin (1973), is the cellular basis for Hebb's Law (see McNaughton, Douglas, \& Goddard, 1978; and many others).

As neuroscientists were closing in on the mechanisms of memory formation, cognitive scientists began to explore connectionist models of memory that eschewed contact with the brain, at least until the mid-1980s. There is no need for us to extensively review the emergence of these models; we wish only to make a few points here. Hebb once again provided the foundation, in that his neuropsychological model was an example of connectionist thinking. Indeed, in the 1950 s there were several attempts to develop cognitive versions of Hebb's ideas, including Rosenblatt's perceptrons (e.g., Rosenblatt, 1958) and Widrow and Hoff's Adaline (e.g., Widrow \& Hoff, 1960). These models, resting on Hebb's thinking and on the logical formalisms proposed by McCulloch and Pitts (1943), ran into certain problems and were largely abandoned for 30 years. Nonetheless, the basic ideas were already in evidence in 1950 . The more recent emergence of PDP models was heralded by the publication of the volumes by McClelland, Rumelhart, and their colleagues $(1986 \mathrm{a}, \mathrm{b})$. Though predicated on an at- tempt to make cognitive models of memory more "brain. like," initially these models paid little more than lip service to the considerable knowledge about brain mechanisms that had been developed in the neurosciences in the previous 30 years. This situtation is only gradually changing, as PDP modelers pay attention to the details of real neural circuits, and the often surprising properties that emerge from these circuits.

PDP models do, however, represent an interesting potential solution to the questions about memory representation that we have been considering. Within these models, representations are distributed across large numbers of elements (read: neurons), and the knowledge inherent in these representations is embodied not only in the elements but also in the connections between elements. Indeed, learning involves changing the strength of these connections, and therefore a memory representation is actually a pattern of connections of a particular strength, or "weight," within a large ensemble of elements. However, McClelland and Rumelhart are quick to point out that their model does not ignore the extensive evidence for cerebral localization of function:

A system that uses distributed representations still requires many different modules for representing completely different kinds of things at the same time. The distributed representations occur within these localized modules. For example, different modules would be devoted to things as different as mental images and sentence structure, but two different mental images would correspond to alternative patterns of activity in the same module. The representations advocated here are local at a global scale but global at a local scale. (1986, Vol. 1, p. 79)

Within such a model, many memories can be superimposed on the same collection of elements, thereby capturing the property of holograms that so attracted van Heerden, without, however, requiring that the brain actually function like a hologram.

\section{Summary}

Early investigations generated insights concerning the nature of memory representations that are still relevant today, For example, Loeb provided strong logical arguments for a (neuroscientific) micro-level analysis into how, and not just where, memory was represented. On the cognitive side, Semon discussed the features of memory engrams, and the manner in which they might be related to retrieval processes. However, most or all of the physiological explanations from these early thinkers through the Gestaltists, were based on speculation (or logic) rather than on empirical evidence. Therefore, whereas the thinking of these early researchers may reflect some degree of convergence between psychological and physiological approaches, the actual experimen- 
tal work did not-again, perhaps because the tools were not available.

Psychologists such as Bartlett showed little interest in physiological discussions, but Lashley brought a background in psychology to bear on his neuroscientific research aimed at finding the engram. Similarly, Hebb (1949) intended his book "to seek a common ground with the anatomist, physiologist, and neurologist, to show them how psychological theory relates to their problems and at the same time to make it more possible for them to contribute to that theory" (p. xii). Here, at least, was a commitment to a convergent agenda.

Until very recently, however, collateral relations between psychological and physiological approaches have been the rule as cognitive and neural scientists interested in memory representations pursued independent research agendas: cognitive psychologists focused on features and attributes, while neuroscientists focused on cellular mechanisms. The recent advent of PDP models, however, promises to help bridge the gap between the two fields. It remains to be seen if PDP formalisms will prove capable of accounting for the vast range of memory phenomena in neurobiologically plausible ways. But at least the pursuit of the engram is now proceeding with both cognitive and neuroscientific constraints in mind.

\section{MEMORY SYSTEMS}

We noted at the outset of the previous section that in addition to providing micro-level analyses of how specific memories are stored, early investigators also offered macro-level hypotheses concerning where memory processes are localized. Such hypotheses led naturally to the suggestion that different forms or types of memory might be localized in different parts of the brain (e.g., Gall, 1835). More recent discussions of this issue have taken the form of debates about whether memory is more usefully viewed as a single, monolithic system or as a collection of multiple interacting systems. Although this debate has been at the forefront of the cognitive, neuropsychological, and neurobiological literatures for the past decade, the roots of the discussion are to be found in nineteenth-century philosophical and medical writings. We consider first these early writings, and then turn our attention to contemporary discussions.

\section{Historical Overview}

\section{Pbilosopby}

One problem that can arise when considering early writings that are relevant to the issue of memory systems is that it is frequently difficult to ascertain whether an author was distinguishing between two or more systems. Because it is all too easy to read current conceptions into past formulations, we will attribute a "multiple mem- ory systems hypothesis" to an author only if an explicit statement arguing for a fundamental difference between types of memories is provided. Consider, for example, the views of the medieval philosopher St. Augustine, presented in a fifth-century treatise. Augustine implied a distinction between memories and habits when he suggested that animals "could not even form their habits except by their memories" (cited in Hermann \& Chafin, 1988 , p. 118). However, he did not provide any reason to assume that memories and habits reflect the operations of different underlying systems; his statement would be equally compatible with the view that there is a single system in which habits are simply overlearned memories.

A similar sort of issue arises when considering the following statement by the thirteenth-century philosopher and theologian Thomas Aquinas: "Pastness can be considered either in relation to the thing known or in relation to the act of knowledge" (cited in Hermman \& Chafin, 1988, p. 147). It is tempting to suggest that "the thing known" refers to an explicit form of memory, and that "the act of knowledge" refers to an implicit form of memory. However, such an inference probably reflects more of our own familiarity with this recently developed distinction than of an explicit hypothesis about multiple memory systems on the part of Aquinas.

To our knowledge, the first clear delineation of a distinction among types of memory in the philosophical literature (or elsewhere) was provided by the French philosopher Maine de Biran (1804/1929), who proposed three types of memory: mechanical, representative, and sensitive (see Schacter, 1987). In Maine de Biran's scheme mechanical memory refers to the acquisition of motor habits, representative memory refers to memory for facts and events, and sensitive memory refers to memory for emotions and feelings. Maine de Biran discussed at great length the properties and functions of these three types of memory, and there can be little doubt that he viewed them as distinct. On the other hand, he was also aware of the difficulties in drawing sharp distinctions among hypothetical mental entities, noting that "The gradation which separates mechanical memory from sensitive memory is, in certain cases, rather difficult to grasp" (Maine de Biran, 1804/1929, p. 163).

More than 100 years after the publication of Maine de Biran's monograph, Bergson (1911)_also a French philosopher-advanced a distinction between forms of memory that is perhaps even more familiar to contemporary students. He argued that "the past survives under two distinct forms: first in motor mechanisms; secondly, in independent recollections" (p. 87). ${ }^{2}$ To illustrate the two hypothesized forms of memory, Bergson used the example of trying to learn a lesson by heart. He contrasted memory for the content of the lesson, on the one hand, with memory for the individual readings that were required to learn it, on the other. He likened the former process to a habit, and suggested that "it is stored up in 
a mechanism which is set in motion as a whole by an initial impulse, in a closed system of automatic movements which succeed each other in the same order and, together, take the same length of time" (p. 90, emphasis added). By contrast, he likened memory for the individual readings required to learn the lesson "to an event in my life; its essence is to bear a date" (p. 90). Bergson also argued for a fundamental difference in how these two types of memory are stored: "the memory of a given reading is a representation, and only a representation" whereas the memory of the learnt lesson "is no longer a representation, it is an action .... I might believe it innate, if I did not choose to recall at the same time, as so many representations, the successive readings by means of which I learnt it. Therefore these representations are independent of it" (p. 91).

The analyses of Maine de Biran and Bergson stand alone among early philosophical discussions in terms of the depth with which they defended and explored distinctions among forms of memory. More recent philosophical treatments include the distinction made by Ryle (1949) between knowing bow and knowing that, which set the stage for later discussions of locale vs. taxon memory systems (O'Keefe \& Nadel, 1978), and procedural vs. declarative memory systems (Anderson, 1976; Cohen \& Squire, 1980). Similarly, Furlong (1951) and Munsat (1966), who distinguished between memory for events and memory for facts, represent a precursor to Tulving's distinction between episodic and semantic memory systems (Tulving, 1972, 1983).

\section{Medical and Psychological Perspectives}

Inquiry into the notion of multiple memory systems also has roots in medical science of the nineteenth century when many researchers argued for distinctions among what they viewed to be fundamentally different kinds of memory. The terminology used by these investigators varied widely; some referred to different "forms of memory," others spoke of different "types of memory," and still others talked about "partial memories." All of them agreed, however, that memory is not a monolithic or unitary entity. Two kinds of evidence were taken as support for this view: (1) within- and between-subject variations of mnemonic ability; and (2) anatomical separation of brain centers and selective impairments of mnemonic function after brain damage.

The observation that the efficacy of different mnemonic abilities varies within and between individuals constituted an important source of evidence for Gall (1835), one of the earliest proponents of a nonunitary view of memory. He objected to the ideas of those practitioners of faculty psychology who saw memory as another indivisible faculty of the mind: "Perception and memory are only attributes common to the fundamental faculties, but not [among] the fundamental faculties them- selves" (p. 251). To support his view, Gall noted, for example, that some people have exceptionally good memory for places, whereas others have unusually good memory for music. If memory constitutes an indivisible faculty, argued Gall, then one would not expect to find variations in the efficacy of mnemonic function across different domains; those who possess good memory in one domain should possess equally good memory in another. Similar logic and evidence were used by the phrenologist Spurzheim (1834) to argue that each fundamental faculty of the mind possesses its own memory: "A person may, therefore, possess an excellent memory of one kind, be very deficient in another, and be without a third entirely" (p. 84). The notion that within- and between-individual variations of mnemonic abilities constitute evidence favoring a distinction among different forms of memory is also apparent in the later work of several late nineteenth- and early twentieth-century writers (e.g., Bascomb, 1901; James, 1890; Luys, 1887). However, the observed differences could also be attributed to the individuals' differing levels of prior knowledge and expertise in the two areas (cf. Fodor, 1983). The realization that such observations do not require the postulation of mutiple forms of memory was first expressed long ago by Ladd (1909), who observed that "the diverse forms of memory are chiefly to be ascribed to diverse tastes and habits, and the interest and attention which accompany them" (p. 138).

A second, rather more compelling class of observations supporting the idea that memory should be divided into different forms derived from reports concerning patients with pathological disorders of memory. Ribot (1882) made explicit the logic that relates ideas about multiple forms of memory to observations of memory pathology: "If, in the normal condition of the organism, the different forms of memory are relatively independent, it is natural that, if in a morbid state one disappears, the others should remain intact" ( $p .142$ ). Ribot cited several cases that he believed were consistent with this hypothesis, and that suggested to him that verbal memory, visual memory, and auditory memory are dissociable. Observations of memory pathology were also used by Lewes (1879) and Claparede (1911/1951) to argue for a nonunitary view of memory much like the one advanced by Ribot.

Although the logic of the argument put forward by Ribot concerning the usefulness of pathological dissociations is fundamentally sound, the evidence cited by Ribot and others was not convincing: It consisted of either anecdotes or uncontrolled observations concerning individual cases of memory impairment. Perhaps because the critical evidence was so weak, it is difficult to find any discussion of the hypothesis of multiple forms of memory for nearly 50 years after the flurry of these turnof-the-century speculations. Instead, throughout the first half of the twentieth century, memory was viewed as a unitary entity by empirically oriented researchers. 
The analysis of memory systems presently occupies center stage in cognitive, neuropsychological, and psychobiological research on memory. As the previous section illustrated, initial speculations about different memory systems were derived from two independent lines of inquiry. Modern conceptions of this issue can also be traced along relatively independent lines of development that have only begun to converge during the past several years.

The first line of investigation derived from studies of intact and brain-lesioned animals. Perhaps the earliest relevant paper was Tolman's (1949) well-known article on forms of learning. Tolman reviewed the parameters of numerous learning paradigms, argued that the evidence pointed toward the existence of more than one form of learning, and in so doing implied that multiple systems were needed to account for the different types of learning that he had delineated. Tolman's analysis, however, focused more on learning than on memory, and did not pursue in any detail the notion of multiple learning systems.

Within the animal literature, the concept of different learning systems emerged more clearly from the debate surrounding place vs. response learning. Two hypotheses were proposed to explain how rats learned to navigate mazes. Hull and followers (e.g., Blodgett \& McCutchan, 1947) argued that rats are guided by simple stimulusresponse behavior, whereas Tolman and supporters (e.g., Tolman, 1948) argued that rats are guided by cognitive maps of a particular place. Could these two hypotheses reflect the operations of two distinct underlying systems? Initially, Restle (1957) suggested that there is no difference between the two types of responses, and that rats simply respond to different cues. However, some years later O'Keefe and Nadel (Nadel \& O'Keefe, 1974; O'Keefe $\&$ Nadel, 1978) contended that two distinct systems-the taxon and locale systems-underlie response and place learning, respectively (see also Hirsh, 1974). O'Keefe and Nadel marshalled various kinds of evidence to support their thesis, including most prominently the fact that lesions in the hippocampal formation disrupted locale, but not taxon, learning (see O'Keefe \& Nadel, 1978, for discussion). They also specified the brain structures that supported the two systems, focusing at length on the role of the hippocampus in the locale system. More generally, they offered an explicit and detailed multiple memory systems hypothesis that was based largely on the animal literature, yet also made use of pertinent observations with human amnesic patients.

At about the same time, Olton and colleagues (e.g., Olton, Becker, \& Handelmann, 1979) put forward a related distinction between working memory and reference memory systems that was motivated by demonstrations of dissociations in rats with hippocampal lesions during performance in an eight-arm radial maze.
The ideas of Olton et al. differed in several respects from those of O'Keefe and Nadel. Most notably, O'Keefe and Nadel argued that the hippocampus (locale system) is involved particularly in spatial memory, whereas Olton and collaborators contended that the hippocampus (working memory system) is involved in storage and retrieval of various types of episodic information. More recently, Sutherland and Rudy (1989) put forward a related distinction between a configural associative system that constructs higher order representations from elementary stimuli and depends on the hippocampus, and a simple associative system that records changes in the strength of associations between stimuli and does not depend on the hippocampus.

The foregoing hypotheses are based largely on studies of rats. Mishkin and colleagues (e.g., Mishkin, Malamut, \& Bachevalier, 1984; Mishkin \& Petri, 1984) advanced a distinction between a memory system and a habit system that is based primarily on studies of nonhuman primates in which lesions to the limbic system impaired memory performance on delayed matching and nonmatching to sample tasks, but spared learning on object discrimination tasks. By this view, what Mishkin et al. label the "memory" system involves cognitive representation, allows for retention of a single episode, and depends on the hippocampus, amygdala, and other limbic structures; by contrast, their "habit" system does not entail any cognitive representation, involves incremental stimulus-response learning, and depends on a corticostriatal system (see also Mahut \& Moss, 1984). Finally, it should also be noted that evidence for multiple memory systems has been reported in other animals, including various species of birds (for review and discussion, see Sherry \& Schacter, 1987).

The second line of pertinent research has been provided by studies of normal and brain-damaged humans. The general issue of multiple memory systems was first brought to the attention of cognitive psychologists by Atkinson and Shiffrin (1968; Shiffrin \& Atkinson, 1969), who put forward what came to be known as the "modal model" of memory. They distinguished between three memory "stores": sensory register, short-term store, and long-term store. Thus, the Atkinson and Shiffrin model focused on different systems that were hypothesized to be involved in short-term and long-term retention. Although the modal model was ultimately deemed too simple, various other proposals for separate systems involved in short-term and long-term retention have been advanced (e.g., Baddeley, 1986; Warrington, 1982).

Within the domain of long-term memory, the hypothesis of multiple memory systems was advanced most forcefully by Tulving $(1972,1983)$ with his well-known distinction between episodic and semantic memory. According to Tulving, the episodic memory system is necessary for context-specific recollection of events from one's personal past, whereas semantic memory subserves 
the acquisition and retrieval of general knowledge. We have already mentioned precursors of this view in the philosophical literature (Bergson, 1911; Furlong, 1951; Munsat, 1966). In addition, the psychologists Reiff and Scheerer (1959) presented a detailed, though far less influential, distinction between memoria and reminiscence in their monograph on memory and hypnotic age regression.

Although Tulving's distinction generated extensive debate and discussion about multiple memory systems (see Tulving, 1983, 1984 for review and discussion), the general issue also received a great deal of cogency from neuropsychological observations reported in studies of brain-damaged amnesic patients. During the 1960s, Milner, Corkin, and colleagues (Milner, 1965; Corkin, 1965, 1968; Milner, Corkin, \& Teuber, 1968) reported the striking observation that the densely amnesic patient H.M. could acquire new motor skills in near-normal fashion despite his inability to recollect the episodes in which he acquired the skills. This dissociation suggested the possibility that motor memory might depend on a different system than memory for facts and episodes (Milner, 1965, 1970; Corkin, 1965). Subsequent research revealed that amnesic patients could acquire other sorts of skills in normal or near normal fashion, including perceptual skills (e.g., Cohen \& Squire, 1980; Moscovitch, 1982; Nissen \& Bullener, 1987) and even some cognitive skills (e.g., Baddeley, 1982; Saint-Cyr, Taylor, \& Lang, 1988; Squire \& Frambach, 1990). These observations led Cohen and Squire (1980; see also, Cohen, 1984; Squire, 1987) to argue for a distinction between a hippocampally based declarative memory system that underlies memory for facts and events, and a procedural memory system that supports acquisition of skills and other spared learning abilities in amnesic patients.

At about the same time that Milner and colleagues performed their investigations of skill learning, Warrington and Weiskrantz $(1968,1974)$ reported their important series of experiments on word completion performance in amnesic patients. They demonstrated that after studying a list of words, amnesic patients showed relatively normal memory performance when given word stems or fragments as cues, despite the fact that they performed quite poorly on standard tests of recognition memory. Warrington and Weiskrantz initially discussed their results in terms of sensitivity to interference and consequent retrieval impairments (see previous section), and not in terms of multiple memory systems; subsequent experimental work was necessary to clarify the precise implications of their observations (cf. Graf, Squire, \& Mandler, 1984; Schacter, 1985b). Nevertheless, their demonstration that severely amnesic patients could show intact facilitation of task performance as a function of prior exposure to a stimulus-a phenomenon now referred to as a priming effect (cf. Shimamura, 1986; Tulving \& Schacter, 1990)-ultimately led to a great deal of empirical research on priming effects in amnesic patients and normal subjects that generated new hypotheses about multiple memory systems. For example, within the neuropsychological literature, a large number of studies have explored the properties and limits of priming in amnesic patients (e.g., Cermak, Talbot, Chandler, \& Wolbarst, 1985; Gabrieli, Milberg, Keane, \& Corkin, 1990; Graf, Shimamura, \& Squire, 1985; Schacter, Cooper, Tharan, \& Rubens, 1991; Schacter \& Graf, 1986).

In the cognitive literature, multiple memory systems hypotheses have been fueled by demonstrations of various kinds of dissociations between priming and remembering. Thus, for example, it has been shown that priming and recall/recognition performance are affected differently by manipulations such as type of study processing (e.g., Jacoby \& Dallas, 1981; Graf \& Mandler, 1984; Schacter, Cooper, \& Delaney, 1990), study/test modality shift (e.g., Graf et al., 1985; Jacoby \& Dallas, 1981; Roediger \& Blaxton, 1987; Schacter \& Graf, 1989), retention interval (e.g., Mitchell \& Brown, 1988; Tulving, Schacter, \& Stark, 1982), and several other variables (for review, see Richardson-Klavehn \& Bjork, 1988; Roediger, 1990; Schacter, 1987). In addition, several studies have revealed that priming shows stochastic independence from recognition memory-that is, the magnitude of priming is uncorrelated with recognition performance (e.g., Hayman \& Tulving, 1989; Jacoby \& Witherspoon, 1982; Schacter et al., 1990; Tulving et al., 1982; but see Hintzman \& Hartry, 1990; Shimamura, 1985).

The dissociations observed in cognitive and neuropsychological studies led to various proposals about different forms of memory. At a descriptive level, Graf and Schacter (1985; Schacter, 1987) advanced a distinction between explicit memory (conscious recollection of experiences) and implicit memory (performance facilitations without conscious recollection). Atlhough the explicit/implicit distinction does not speak directly to the question of whether different systems underlie the two forms of memory, other proposals do. As noted earlier, the distinction between declarative and procedural memory systems was put forward intially to accommodate findings of preserved skill learning in amnesic patients. Although it was suggested that priming effects also depend on the procedural system (e.g., Cohen, 1984; Squire, 1986), subsequent research with dementia patients revealed a double dissociation between priming and skill learning-Alzheimer patients showed intact skill learning and impaired priming whereas Huntington's disease patients showed impaired skill learning and intact priming (Heindel, Salmon, Shults, Walicke, \& Butters, 1989)-thereby indicating that the two phenomena do not depend on the same underlying system (cf. Heindel et al., 1989; Schacter, 1987; Squire, 1987). Based on the neuropsychological evidence, together with the previously mentioned research on preserved habit learning in nonhuman primates, a number of investigators proposed that various skill learning phenomena are mediated by a corticostriatal system that functions 
independently of the hippocampally based episodic or declarative memory system (Heindel et al., 1989; Mishkin et al., 1984; Sherry \& Schacter, 1987; Squire, 1987).

Proposals have also been made regarding memory systems that are involved in priming, and by implication, spared in amnesic patients. One possibility is that priming involves a semantic memory system (e.g., Cermak et al., 1985), but various properties of the phenomenon cast doubt on this idea (see Roediger, 1990; Schacter, 1990; Tulving et al., 1982). Hayman and Tulving (1989) proposed that priming reflects the operation of a "traceless," "quasi-memory" system that functions independently of episodic and semantic memory, but they did not relate this hypothetical system to underlying brain structures. Schacter and colleagues (Schacter, 1990; Schacter et al., 1990, 1991; Tulving \& Schacter, 1990) proposed that many priming effects reflect the operation of a presemantic perceptual representation system (PRS) that is in turn composed of several subsystems: each subsystem is dedicated to the representation and retrieval of the form and structure, but not the meaning and associative properties, of words (word form subsystem) and objects (structural description subsystem; see also, Gabrieli et al., 1990 and McCarthy \& Warrington 1990 for a discussion of neuropsychological evidence). By this view, the various PRS subsystems depend on posterior cortical structures, such as inferior temporal regions and extrastriate occipital cortex.

It must also be noted that although the evidence for some form of multiple memory systems hypothesis is compelling to many, a number of cognitive psychologists have claimed that it is not necessary to postulate different memory systems, preferring instead the idea of a single but flexible memory system (e.g., Jacoby, 1983; Masson, 1989; Roediger, 1990; Roediger \& Blaxton, 1987). By their view, observed dissociations between different types of memory tests can be accounted for in large part by the degree of overlap between cognitive operations performed at study and test. Although this view can account for many of the implicit/explicit dissociations observed in normal subjects, it has a rather more difficult time coming to grips with findings of preserved implicit memory in severely amnesic patients (Hayman \& Tulving, 1989; Schacter, 1987, 1990).

\section{Summary}

Early philosophers and scientists discussed the possibility of multiple forms of memory from quite different perspectives, and the types of memory they posited differed substantially. In particular, philosophers such as Maine de Biran and Bergson, who offered hypotheses that were couched at the psychological level, stressed a difference between a mechanical/habit system and "actual" memories. By contrast,investigators who focused on the physiological level postulated different memories for different faculties (e.g., Gall, 1835) or sense modalities (e.g., Ribot, 1882). Only when clinical accounts of phenomena now referred to as implicit memory began to appear in reports of amnesic patients (e.g., Claparede, 1911; Korsakoff, 1889/1955) did medical scientists begin to investigate the kind of distinction that had been drawn by philosophers. There was essentially no interaction between those few investigators who offered hypotheses about multiple forms of memory at either psychological or physiological levels, thereby reflecting the existence of collateral relations between the two approaches.

More recently, the research programs of cognitive psychology and neuroscience have shown a much higher degree of overlap; investigations of multiple memory systems in each domain are having substantial impact on pertinent studies in the other. Thus, neuroscientists who investigate memory in nonhuman animals have been influenced by neuropsychological studies of human amnesia (cf. Mishkin et al., 1984; O'Keefe \& Nadel, 1978; Olton, 1989). Similarly, neuropsychologists who study human amnesic patients have likewise made use of findings and ideas from studies of animals (e.g., Cohen, 1985; Schacter, 1985a; Squire, 1987; Weiskrantz, 1989). Moreover, there are now a number of papers concerned with the issue of multiple memory systems that represent collaborations between researchers who focus on either human or animal investigations (e.g., Eichenbaum, Fagan, Mathews, \& Cohen, 1988; Schacter \& Nadel, 1991; Sherry \& Schacter, 1987; Moscovitch, Winocur, \& McLachlan, 1986; Zola-Morgan \& Squire, 1985).

It is interesting to note that nearly all of the existing convergence between the animal and human literatures focuses on the general distinction between a memory system that subserves recall or recognition of specific items/episodes on the one hand, and a habit or skill learning system that is involved in incremental response acquisition on the other. By contrast, whereas memory systems have been postulated in the human cognitive and neuropsychological literatures to accommodate dissociations between priming and recall or recognition performance (e.g., Schacter, 1990; Squire, 1987; Tulving $\&$ Schacter, 1990), there are as yet no corresponding ideas and studies in the animal literature. This situation likely reflects the difficulties inherent in adapting to animal studies paradigms from the human literature that permit experimental separation of priming from other forms of memory. It is a somewhat more straightforward matter to adapt and compare skill learning paradigms in studies of humans and other animals, which may account for the observed convergence in this area of the literature.

A second area of convergent relations can be identified within the human literature. Specifically, cognitive studies of intact subjects and neuropsychological investigations of amnesic patients are currently exploring similary hypotheses about multiple memory systems. This trend is particularly evident in research on priming phenom- 
ena where cognitive and neuropsychological studies show a high degree of cross-fertilization and mutual influence (cf. Cermak et al, 1985; Graf et al., 1984, 1985; Graf \& Schacter, 1985; Jacoby \& Witherspoon, 1982; Roediger \& Blaxton, 1987; Hayman \& Tulving, 1989; Moscovitch, Winocur, \& McLachlan, 1986; Schacter, 1985b, 1990; Schacter et al., 1991; Tulving, Hayman, \& MacDonald, 1991). It should also be noted, however, that a similarly high degree of convergent relations is not yet evident in studies of skill learning that bear on the issue of multiple memory systems. Although paradigms from cognitive psychology have been used to study skill learning in amnesia (e.g., Cohen \& Squire, 1980; Moscovitch, 1982), and some cognitive psychologists have made note of pertinent findings with amnesic patients (e.g., Singely \& Anderson, 1989), the voluminous cognitive literature on various types of skill learning (e.g., Anderson, 1981; Kelso, 1982; Singley \& Anderson, 1989) has had little impact on neuropsychological research, which in turn has had at best a modest influence on cognitive studies. Progress in both areas would likely be facilitated if each paid greater attention to the other.

\section{CONCLUSION}

In this article we have taken a historical look at cognitive neuroscience analyses of memory, focusing on issues of consolidation, the nature of memory representations, and multiple memory systems. We will conclude by noting several general trends.

First, it seems clear that the sort of sustained interdisciplinary analyses of memory that are essential to the development of cognitive neuroscience constitute a relatively rare historical phenomenon. Although such early thinkers as Burhham, Loeb, Ribot, and Semon all made some attempts to link psychological and physiological perspectives, there have only been a few-and all of them recent--examples of what we have referred to as convergent relations between cognitive and neuroscientific approaches. For the most part, previous attempts at "cognitive neuroscience" have taken the form of informed (and sometimes ingenious) speculations rather than of systematic empirical research. These speculations reflect the existence of what we have termed complimentary relations, where concepts or ideas from one discipline are used to supplement theorizing in another discipline. Although this likely reflects limitations on the methodological tools that were available to earlier investigators, it does serve to highlight the fact that the development of an empirical cognitive neuroscience of memory represents a relatively recent development.

A second, related point to emerge from our discussion is that prior efforts to link cognitive and neuroscientific approaches have frequently entailed some type of reductionist strategy; that is, an attempt to explain a psychological phenomenon at a more "basic" physiological level of analysis. Such attempts are not without merit: they help to focus attention on fundamental problems that are of interest both to cognitive scientists and neuroscientists, and reduce the likelihood that researchers in each discipline will become mired in the details of specific paradigms and procedures at the expense of global perspectives. Indeed, one could argue that thinking about global issues regarding consolidation, memory representations, and multiple memory systems has been aided by prior speculations of this kind, in the sense that they focus attention on the forest rather than the trees.

Nevertheless, we also think that cognitive neuroscience analyses or memory must involve more than simple attempts at reductionism. Interdisciplinary interactions will be most fruitful when insights from one level of analysis can inform and enlighten developments at another level of analysis; that is, when neuroscientific findings and ideas can inform cognitive research at the psychological level of analysis, and when cognitive findings and ideas can inform neuroscientific research at the physiological level of analysis (see Nadel \& O'Keefe, 1974; Schacter, 1986). It is just this sort of interaction that is characteristic of convergent relations, and we can see the beginnings of it in some of the recent research in each of the three areas that we have considered.

A third point to note is that an interdisciplinary orientation encourages the investigation of certain questions that demand both neural and cognitive approaches. Consider, for example, the problem of determining how long information is stored in the hippocampal formation. The logic of much of the research on retrograde amnesia and consolidation depends on the assumption that the hippocampus is the site of memory storage (for certain kinds of information) for only a limited period of time, during which a permanent engram is being formed elsewhere. As we have seen, the evidence used to support this claim comes primarily from lesion studies, which indicate that after a certain retention interval, performance no longer requires an intact hippocampal formation. Zola-Morgan and Squire (1990), for example, showed that after 8 weeks, hippocampal lesions did not prevent normal performance on preoperatively acquired visual object discrimination problems. The authors interpret these data as evidence for a time limitation on memory storage in the hippocampus, but it is not clear whether these kinds of data alone can support such a claim. Because they were obtained in animals without a hippocampus, they cannot by definition address the presence or absence of memories in the hippocampus. All that such data can show is that adequate memory is established outside the hippocampus over a specific time period. The same logical limits apply to studies of retrograde amnesia in human patients with focal brain dam. age. The fact that information stored outside the hippocampus can at some time support memory performance does not demonstrate that memory within the 
hippocampus has faded away. This latter claim can be investigated only in studies of animals (or humans) with an intact hippocampus that explore cognitive aspects of memory performance with appropriate behavioral tests, and relate them to relevant neurophysiology, perhaps with a noninvasive imaging technique. Interdisciplinary research is well-suited for, and is even a necessary condition of, resolving this kind of issue.

Although we have focused on the merits of interdisciplinary research programs, we have paid little attention to what some might see as their great limitation: only certain levels of each discipline can be meaningfully discussed in terms of the other. Cohen (1985) referred to the problem in general by discussing "the difficulty in deriving a complete understanding of learning and memory that encompasses all levels of analysis" (p. 428). Although neuroscientists may have the tools to investigate cellular/neuronal changes that mediate memory, unless these changes can be directly related to observed behavioral differences at the cognitive level, studying them is of little use to an interdisciplinary research program. Similarly, while encoding operations are clearly related to memory performance, unless these operations can be mapped onto recognized neurophysiological changes in a meaningful fashion, their investigation is of little value to an interdisciplinary approach. There is clear value to an interdisciplinary program for memory research, but it is not the only way for memory research to proceed. Indeed, certain technological or methodological advances can be accomplished only by concentrating on the problems intrinsic to a particular discipline. Nevertheless, we are optimistic that progress in understanding memory will be facilitated by the establishment of convergent relations between cognitive and neuroscientific approaches, and that such an agenda can help to bridge the gap between mind and brain at many levels of analysis.

\section{Acknowledgments}

This article was supported by a grant from the McDonnell-Pew Cognitive Neuroscience Program. Daniel Schacter is now at the Department of Psychology, Harvard University. Correspondence concerning this article and reprint requests should be addressed to Michael R. Polster, Department of Psychology, University of Arizona, Tucson, Arizona 85721.

\section{Notes}

1. Because the terms "cognitive psychology" and "neuroscience" refer to relatively modern fields of investigation, we use the more general terms "psychology" and "physiology" as historical antecedents of each.

2. The former type of memory corresponds closely to Maine de Biran's mechanical memory, and the latter to his representative memory. Given the similarity between the two conceptualizations, and the strong influence that Maine de Biran exerted on subsequent French philosophers and psychologists (Ellenberger, 1970), it is possible that Bergson's ideas about forms of memory were to some extent based on the 1804 monograph. However, Bergson did not discuss or even cite Maine de Biran in his 1911 book, and there is no firm evidence that shows a direct influence.

\section{REFERENCES}

Albert, M. S., Butters, M., \& Levin, J. (1979). Temporal gradients in the retrograde amnesia of patients with alcoholic Korsakoff's disease. Archives of Neurology, 36, 211-216.

Anderson, J. R. (1976), Language, memory, and thought. Hillsdale, NJ: Lawrence Erlbaum Associates.

Anderson, J. R. (1981). Cognitive skills and their acquisition. Hillsdale, NJ: Lawrence Erlbaum.

Atkinson, R. C., \& Shiffrin, R. M. (1968). Human memory: A proposed system and its control processes. In K. W. Spence \& J. T. Spence (Eds.), The psychology of learning and motivation (Vol. 2, pp. 89-195). New York: Academic Press.

Baddeley, A. D. (1982). Amnesia: A mimimal model and an interpretation. In L. S. Cermak (Ed.), Human memory and amnesia. Hillsdale, NJ: Lawrence Erlbaum Associates.

Baddeley, A. D. (1986). Working Memory. Oxford: Clarendon Press.

Ballard, P. B. (1913). Oblivescence and reminiscence. British Journal of Psychology Monograph Supplements, 1(2).

Bartlett, F. C. (1932). Remembering: A study in experimental and social psycbology. Cambridge: Cambridge University Press.

Bascomb, J. (1901) The science of mind. New York: G. P. Putnam.

Bergson, H. (1911). Matter and memory (N. M. Paul \& W. S. Palmer, Trans.). London: Swan Sonnenschein \& $\mathrm{Co}$.

Bliss, T. V. P., \& Gardner-Medwin, A. R. (1973). Long-lasting potentiation of synaptic transmission in the dentate area of the unanaesthetised rabbit following stimulation of the perforant path. Journal of Physiology (London), 232, 357-374.

Bliss, T. V. P., \& Lømo, T. (1973). Long-lasting potentiation of synaptic transmission in the dentate area of the anaesthetised rabbit following stimulation of the perforant path. Joumal of Physiology (London), 232, 331-356.

Blodgett, H. C., \& McCutchan, K. (1947). Place versus response learning in the simple $\mathrm{T}$ maze. Journal of Experimental Psychology, 37, 412-422.

Bonaparte M., Freud, A., \& Kris, E. (1954). The origins of psycho analysis: Letters to Wilhelm Fliess, drafts and notes: 1887-1902 (E. Masbacher \& J. Strachey, Trans.). New York: Basic Books.

Bower, G. (1967). A multicomponent theory of the memory trace. In K. W. Spence \& J. T. Spence (Eds.), The psycbology of learning and motivation (Vol. 1). New York Academic Press.

Brady, J. V. (1951). The effect of electroconvulsive shock on a conditioned emotional response: The permanence of the effect. Journal of Comparative and Physiological Psychology; 44, 507-511.

Brady, J. V. (1952). The effect of electroconvulsive shock on a conditioned emotional response: The significance of the interval between the emotional conditioning and the electroconvulsive shock. Joumal of Comparative and Phrsiological Psychology 45, 9-13.

Brady, J. V., \& Hunt, H. F. (1951). A further demonstration of the effects of electro-convulsive shock on a conditioned emotional response. Joumal of Comparative and Pbysiological Psychology, 44, 204-209.

Brown, J. (1958). Some tests of the decay theory of immediate memory. Quarterly Joumal of Experimental Psycbology, $10,12-21$. 
Broca, P. (1861). Remarques sur le siege de la faculte du langage articule suivie d'une observation d'aphémie. Bull. Soc Anat., Paris, 6, 330. Trans, in R. Herrnstein \& E. G. Boring, 1965, A source book in the bistory of psychology. Cambridge, MA: Harvard University Press.

Burnham, W. H. (1903). Retroactive amnesia: Illustrative cases and a tentative explanation. American Journal of Psychology, 14, 382-396.

Buxton, C. E. (1943). The status of research on reminiscence. Psychological Bulletin, 40, 313-340.

Cermak, L. S., Talbot, N., Chandler, K, \& Wolbarst, L. R. (1985). The perceptual priming phenomenon in amnesia. Neuropsychologia 23, 615-622.

Chorover, S. (1976). An experimental critique of "consolidation studies" and an alternative "model-systems" approach to the biophysiology of memory. In M. R. Rosenzweig \& E. L. Bennett (Eds.), Neural mechanisms of learning and memory. Cambridge, MA: MIT Press.

Claparede, E. (1911/1951). Recognition and Me-ness. In D. Rapaport (Trans. \& Ed.), Organization and patbology of thought. New York: Columbia University Press.

Cohen, N. J. (1984). Preserved learning capacity in amnesia: Evidence for multiple memory systems. In L. R. Squire \& N. Butters (Eds.), Neuropsychology of memory. New York: Guilford Press.

Cohen, N. J. (1985). Levels of analysis in memory research: The neuropsychological approach. In N. M. Weinberger, J. L. McGaugh, \& G. Lynch (Eds.), Memory systems of the brain. New York: Guilford Press.

Cohen, N. J., \& Squire, L. R. (1980). Preserved learning and retention of pattern analyzing skill in amnesia: Dissociation of knowing how and knowing that. Science, 10, 207-209.

Coons, E. E., \& Miller, N. E. (1960). Conflict versus consolidation of memory traces to explain "retrograde amnesia" produced by ECS. Iournal of Comparative and Phisiological Psucbology, 53, 524-531.

Corkin, S. (1965). Tactually-guided maze learning in man: Effect of unilateral cortical excision and bilateral hippocampal lesions. Neuropsychologia, 3, 339-351.

Corkin, S. (1968). Acquisition of motor skill after bilateral medial temporal lobe excision. Neuropsycbologia, 6, 255265.

Crowder, R. G. (1989). Modularity and dissocations in memory systems. In H. L. Roediger \& F. I. M. Craik (Eds.), Varieties of memory and consciousness. Hillsdale, NJ: Lawrence Erlbaum.

Dean, P., \& Weiskrantz, L. (1974). Loss of preoperative habits in rhesus monkeys with inferotemporal lesions: Recognition failure or relearning deficit? Neuropsychologia. 12, 299-311.

DeCamp, J. E. (1915). A study of retroactive inhibition. Psychological Monographs, 19 (4, whole no. 84).

Duncan, C. P. (1949). The retroactive effect of electroshock on learning. Journal of Combarative and Physiological Psvchology. 42, 32-44.

Ebbinghaus, H. (1885/1964). Memory: A contribution to experimental psychology (H. A. Ruger \& C. E. Bussenius, Trans.). New York: Dover.

Eich, J. E. (1982). A composite holographic associative recall model. Psichological Review 89, 627-661.

Eichenbaum, H., Fagan, A., Mathews, P., \& Cohen, N. J. (1988) Hippocampal system dysfunction and odor discrimination learning in rats: Impairment or facilitation depending on representational demands. Bebavioral Neuroscience, 102, 331-339.

Ellenberger, H. F. (1970). The discovery of the unconscious. New York: Basic Books.

Estes, W. K., \& Skinner, B. F. (1941). Some quantitative prop- erties of anxiety. Joumal of Experimental Psychology, 29, $390-400$.

Flourens, M.-J.-P. (1824). Recherches expérimentales sur les propriétés et fonctions due systeme nerveux dans les animaus vertébrés. Paris.

Fodor, J. A. (1983). The modularity of mind. Cambridge, MA: MIT Press

Furlong, E. J. (1951). A study of memory. London: Thomas Nelson.

Gabrieli, J. D. E., Milberg, W., Keane, M. W., \& Corkin, S. (1990). Intact priming of patters despite impaired memory. Neurobsuchologia 28, 417-428.

Gall, F. J. (1835). The influence of the brain on the form of the head (W. Lewis, Trans.). Boston: Marsh, Capen, \& Lyon

Gerard, R. W. (1955). Biological root of psychiatry. Science. 122, 225-230.

Glickman, S. E. (1958). Deficits in avoidance learning produced by stimulation of the ascending reticular formation. Canadian Journal of Psychology, 12, 97-102.

Glickman, S. E. (1961). Perseverative neural processes and consolidation of the memory trace. Psychological Bulletin, 58(3), 218-233.

Gold, P. E., \& McGaugh, J. L. (1975). A single-trace, two-process view of memory storage processes. In D. Deutsch \& A J. Deutsch (Eds.), Short term memory. New York: Academic Press.

Gomulicki, B. R. (1953). The development and present status of the trace theory of memory. British Journal of Psychology Monographs, Suppl. 29, 1-94.

Graf, P., \& Mandler, G. (1984). Activation makes words more accessible, but not necessarily more retrievable. Journal of Verbal Leaming and Verbal Behavior 23, 553-568.

Graf, P., \& Schacter, D. L. (1985). Implicit and explicit memory for new associations in normal and amnesic subjects. loumal of Experimental Psuchology: Leaming Memorv $\mathcal{E}$ Cognition 11, 501-518.

Graf, P., Shimamura, A. P., \& Squire, L. R. (1985). Priming across modalities and priming across category levels: Extending the domain of preserved function in amnesia. Journal of Experimental Psychology: Learning, Memory, $\hat{\sigma}$ Cognition, 11, 385-395.

Graf, P., Squire, L. R., \& Mandler, G. (1984). The information that amnesic patients do not forget. Ioumal of Experimental Psuchology: Leaming Memorv E Cognition. 10, 164178.

Hayes, K. J. (1953). Anoxic and convulsive amnesia in rats. Ioumal of Comparative Phusiological Psvchology 46, 216217.

Hayman, C. A. G., \& Tulving, E. (1989). Contingent dissociation between cognition and fragment completion: The method of triangulation. Journal of Experimental Psychology: Learning, Memory \& Cognition, 15, 222-248.

Head, H., \& Holmes, G. (1912). Sensory disturbances from cerebral lesions. Brain 34, 102-254.

Hebb, D. O. (1949). The organization of bebavior: A neuropsycbological theory. New York: John Wiley.

Heindel, W. C., Salmon, D. P., Shults, C. W., Walicke, P., \& Butters, N. (1989). Neuropsychological evidence for multiple implicit memory systems: A comparison of Alzheimer's, Huntington's, and Parkinson's disease patients. Journal of Neuroscience, $9(2), 582-587$.

Herrmann, D. J., \& Chaffin, R. (1988). Memory in bistorical perspective: The literature before Ebbinghaus. New York: Springer-Verlag.

Hilgard, E. R., \& Bower, G. (1966). Theories of learning (3rd ed.). New York: Appleton-Century-Crofts.

Hintzman. D. L., \& Hartry, A. L. (1990). Item effects in recognition and fragment completion: Contingency relations vary 
for different subsets of words. Iournal of Experimental Psychology: Leaming, Memory \& Cognition, 16(6), 955969.

Hirsh, R. (1974). The hippocampus and contextual retrieval of information from memory: A theory. Behavioral Biology $12,421-444$.

Hunt, H. F., \& Brady, J. V. (1951). Some effects of electroconvulsive shock on a conditioned emotional response ("anxiety"). Journal of Comparative and Phvsiological PSVchology 44, 88-98.

Jacoby, L. L. (1983). Perceptual enhancement: Persistent effect of an experience. Memory and Cognition, 9, 21-38.

Jacoby, L. L., \& Dallas, M. (1981). On the relationship between autobiographical memory and perceptual learning. Journal of Experimental Psvchology: General, 110, 306-340.

Jacoby, L. L., \& Witherspoon, D. (1982). Remembering without awareness. Canadian Journal of Psychology, 36, 300-324.

James, W. (1890). The principles of psychology (Vol. 1). New York: Henry Holt.

Jenkins, J. G., \& Dallenbach, K. M. (1924). Obliviscence during sleep and waking. American Journal of Psychology 35, 605-612.

Kean, M.-L., \& Nadel, L. (1982). On the emergence of cognitive neuroscience. In J. Mehler, E. C. T. Walker, \& M. Garrett (Eds.), Perspectives on mental representation. Hillsdale, N.J.: Lawrence Erlbaum Associates.

Kelso, J. A. S. (1982). Human motor behavior: An introduction. Hillsdale, NJ: Lawrence Erlbaum.

Koffka, K. (1935). Principles of Gestalt psycbology. New York: Harcourt, Brace \& World.

Kohler, W. (1947). Gestalt psychology. New York: Liveright.

Konorski, J. (1948). Conditioned reflexes and neuron organization (S. Garry, Trans.). Cambridge: Cambridge University Press.

Korsakoff, S. S. (1889/1955). Über eine besondere Form psychischer Storung, Kombiniert mit multiplen Neuritis. Archiv für Psvcbiatrie und Nervenkrankbeiten, 21, 669-704. Trans. by M. Victor \& P. I. Yakovlev, in Neurology, 5, 384-406.

Kubie, J. L., Dayyani, S. Muller, R. U., Cohen, B., Major, E., \& Sutherland, R. J. (1990). Hippocampal lesions in rats produce a temporally graded retrograde amnesia on a spatial memory task. Society Neuroscience Abstracts, 16, 1246.

Kussmaul, A. (1877). "Die Störungen der Sprache," in Ziemssen's Handbuch der speciellen Pathologie und Therapie. Leipzig. XII, Anhang 1-300.

Ladd. G. T. (1909). Oulines of descriptive psychology. New York: Charles Scribner's.

Lashley, K. S. (1918). A simple maze: With data on the relation of the distribution of practice to the rate of learning. Psychobiology 1, 353-367.

Lashley, K. (1950). In search of the engram. Symposium Society of Experimental Biology (no. 4). Cambridge: Cambridge University Press.

Leukel, F. P. (1957). The effect of ECS and pentothal anaesthesia on maze learning and retention. Ioumal of Comparative and Physiological Psvchologv 50, 300-306.

Lewes, G. H. (1879). Problems of life and mind. London: Trübner and Co.

Lewis, D. J. (1969). Sources of experimental amnesia, Psycbological Review 76(5), 461-472.

Loeb, J. (1901/1973). Comparative physiology of the brain and comparative psychology. New York: Arno Press.

Lømo, T. (1966). Frequency potentiation of excitatory synaptic activity in the dentate area of the hippocampal formation. Acta Physiologica Scandinavica, 68 (suppl. 277), 128.

Luys, J. B. (1887). The brain and its function. New York: D. Appleton.

Mahut, H., \& Moss, M. (1984). Consolidation of memory: The hippocampus revisited. In L. R. Squire \& N. Butters (Eds.), Neuropsychology of memory. New York: Guilford Press.

Maine de Biran, P. (1804/1929). The infuence of babit on the faculty of thinking (M. D. Boehm, Trans.). Baltimore: Williams \& Wilkins.

MacCurdy, J. T. (1928). Common principles in psychology and physiology. Cambridge, MA: Harvard University Press.

Marslen-Wilson, W. D., \& Teuber, H.-L. (1975). Memory for remote events in anterograde amnesia: Recognition of public figures from newsphotographs. Neurotsvichologia. 13, 353-364.

Masson, M. E. J. (1989). Fluent reprocessing as an implicit expression of memory for experience. In S. Lewandowsky, J. Dunn, \& K. Kirsner (Eds.), Implicit memory: Theoretical issues. Hillsdale, NJ: Lawrence Erlbaum.

McCarthy, R. A., \& Warrington, W. K. (1990). Cognitive neuropsychology: A clinical introduction. San Diego: Academic Press.

McClelland, J. L., \& Rumelhart, D. E. (1986a). Parallel distributed processing: Explorations in the microstructure of cognition (Vol. 1). Cambridge, MA: MIT Press.

McClelland, J. L., \& Rumelhart, D. E. (1986b). Parallel distributed processing: Explorations in the microstructure of cognition (Vol. 2). Cambridge, MA: MIT Press.

McCulloch, W. S., \& Pitts, W. (1943). A logical calculus of the ideas immanent in nervous activity. Bulletin of Mathematical Biobhusics, 5, 115-133.

McDougall, W. (1901). Experimentelle Beitrage zur Lehre von Gedachtniss: Von G. E. Müller und A. Pilzecker. Mind, 10, 388-394.

McDougall, W. (1911). Body and mind. London: Metheun.

McGaugh, J. L., \& Dawson, R. G. (1971). Modifications of memory storage processes. Behavioral Science 16, 45-63.

McGaugh, J. L., \& Gold, P. E. (1976). Modulation of memory by electrical stimulation of the brain. In M. R. Rosenzweig \& E. L. Bennett (Eds.), Neural mechanisms of learning and memory. Cambridge, MA: MIT Press.

McGeogh, J. A. (1932). Forgetting and the law of disuse. Psychological Review, 39, 352-370.

McNaughton, B. L., Douglas, R. M., \& Goddard, G. V. (1978). Synaptic enhancement in fascia dentata: Cooperativity among coactive afferents. Brain Research 157, 277-293.

Melton, A. W. (1963). Implications of short-term memory for a general theory of memory. Journal of Verbal Leaming and Verbal Behavior 2, 1-21.

Miller, N. E., \& Coons, E. E. (1955). Conflict versus consolidation of memory to explain "retrograde amnesia" produced by ECS. American Psychologist, 10, 394-395 (Abstract).

Miller, R. A., \& Marlin, N. A. (1984). The physiology and semantics of consolidation. In $\mathrm{H}$. Weingartner \& E. S. Parker (Eds.), Memory consolidation. Hillsdale, NJ: Lawrence Erlbaum.

Miller, R. A., \& Springer, A. D. (1973). Amensia, consolidation, and retrieval. Psvchological Review 80, 69-79.

Milner, B. (1965). Memory disturbance after bilateral hippocampal lesions. In P. M. Milner \& S. Glickman (Eds.), Cognitive processes and the brain. Princeton, NJ: Van Nostrand.

Milner, B. (1970). Memory and the medial temporal relations of the brain. In K. H. Pribram \& D.E. Broadbent (Eds.), Biology of memory. New York: Academic Press.

Milner, B., Corkin, S., \& Teuber, H-L. (1968). Further analysis of hippocampal amnesic syndrome: 14 year follow-up study of H.M. Neurobsuchologia. 6, 215-234.

Mishkin, M., Malamut, B., \& Bachevalier, J. (1984). Memories and habits: Two neural systems. In G. Lynch, J. L. McGaugh, \& N. M. Weinberger (Eds.), The neurobiology of learning and memory. New York: Guilford Press.

Mishkin, M, \& Petri, H. L. (1984). Memories and habits: Some 
implications for the analysis of learning and retention. In $\mathrm{L}$. Squire \& N. Butters (Eds.), Neuropsychology of memory. New York: Guilford Press.

Mitchell, D. B., \& Brown, A. S. (1988). Persistent repetition priming in picture naming and its dissociation from recognition memory. Joumal of Experimental Psychology: Leaming Memory and Cognition, 14(2), 213-222.

Moscovitch, M. (1982). Multiple dissociations of function i amnesia. In L. Cermak (Ed.), Human memory and amnesia. Hillsdale, NJ: Lawrence Erlbaum.

Moscovitch, M., Winocur, G., \& McLachlan, D. (1986). Memory as assessed by recognition and reading time in normal and memory-impaired people with Alzheimer's disease and other neurological disorders. Journal of Experimental PSychology: General 115, 331-347.

Müller, G. E., \& Pilzecker (1900). A. Experimentelle Beitrage zur Lehre vom Gedachtniss [Experimental contributions ot the theory of memory]. A. Psycbol, 1, 1-288.

Munk, H. (1881). Ueber die Funtionen der Grosshirnrinde. Berlin.

Munsat, S. (1966). The concept of memory. New York: Random House.

Murdock, B. B. (1982). A theory for the storage and retrieval of item and associative information. Psvchological Review, $89,609-626$.

Nadel, L., \& O'Keefe, J. (1974). The hippocampus in pieces and patches: An essay on modes of explanation in physiological psychology. In R. Bellairs \& E. G. Gray (Eds.), Essays on the nervous system. A festschrift for Prof. J. Z. Young. Oxford: Clarendon Press.

Nissen, M. J., \& Bullemer, P. (1987). Attentional requirements of learning: Evidence from performance measures. Cognitive Psuchology 19, 1-32.

O'Keefe, J., \& Nadel, L. (1978). The bippocampus as a cognitive map. Oxford: Clarendon Press.

Olton, D. S. (1989). Inferring psychological dissociations from experiment dissociations: The temporal context of episodic memory. In H. L. Roediger, III \& F. I. M. Craik (Eds.), Varieties of memory and consciousness: Essays in bonour of Endel Tulving. Hillsdale, NJ: Lawrence Erlbaum.

Olton, D. S., Becker, J. T., \& Handelmann, G. E. (1979). Hippocampus, space and memory. Bebavioral and Brain Sciences, 2, 313-365.

Payne, D.G. (1987). Hypermnesia and reminiscence in recall: A historical and empirical review. Psychological Bulletin 101, 5-27.

Peterson, L. R., \& Peterson, M.J. (1959). Short-term retention of individual verbal items. Journal of Experimental Psychology, 58, 193-198.

Pieron, H. (1929). Principles of experimental psychology. London: Kegan Paul, Trench, Trubner \& Co.

Pribram, K. H. (1971). Languages of the brain: Experimental paradoxes and principles in neuropsychology. Englewood Cliffs, NJ: Prentice-Hall.

Ransmeier, R. E., \& Gerard, R. W. (1954). Effects of temperature, convulsion and metabolic factor on rodent memory and EEG. American Journal of Physiology, 179, 663-664 (Abstract)

Reiff, R., \& Scheerer, M. (1959). Memory and bypnotic age regresion: Developmental aspects of cognitive function explored tbrough bypnosis. New York: International Universities Press, Inc.

Restle, F. (1957). Discrimination of cues in mazes: A resolution of the 'place-vs-response' question. Psychological Review, 74, 151-182.

Ribot, T. (1882). Diseases of memory. New York: Appleton. Ribot, T. (1892). Memory. In D. H. Tuke (Ed.), A dictionary of psychological medicine. Philadelphia: Blakiston.
Richardson-Klavehn, A., \& Bjork, R. A. (1988). Measures of memory. Annual Review of Psychology 39, 475-543.

Roediger, H. L. III (1990). Implicit memory: Retention without remembering American Psvchologist, 45, 1043-1056.

Roediger, H. L. III, \& Blaxton, T. A. (1987). Retrieval modes produce dissociations in memory for surface information. In D.S. Gorfein \& R, R. Hoffman (Eds.), Memory and cognitive processes: The Ebbingbaus Centennial Conference. Hillsdale, NJ: Lawrence Erlbaum Associates.

Roediger, H. L. III, \& Payne, D. G. (1982). Hypermnesia: The role of repeated testing. Joumal of Experimental Psychol. ogy: Learning, Memory, \& Cognition, 8(1), 66-72.

Rosenblatt, F. (1958). The perceptron: A probabilistic model for information storage and organization in the brain. Psychological Review 65, 386-408.

Ryle, G. (1949). The concept of mind. San Francisco: Hutchinson.

Saint-Cyr, J. A., Taylor, A., \& Lang, A. (1988). Procedural learning and neostriatal dysfunction in man. Brain 111, 941959.

Salmon, D., Zola-Morgan, S., \& Squire, L. R. (1987). Retrograde amnesia following combined hippocampal-amygdal lesions in monkeys. Psychobiology, 15, 37-47.

Sanders, H. I., \& Warrington, E. K. (1971). Memory for re mote events in amnesic patients. Brain, 94, 661-668

Schacter, D. L. (1982). Stranger bebind the engram: Theories of memory and the psychology of science. Hillsdale, NJ: Lawrence Erlbaum.

Schacter, D. L. (1985a). Multiple forms of memory in humans and animals. In N. Weinberger, J. McGaugh, \& G. Lynch (Eds.), Memory systems of the brain: Animal and buman cognitive processes. New York: Guilford Press.

Schacter, D. L. (1985b). Priming of old and new knowledge in amnesic patients and normal subjects. Annals of the New York Academv of Sciences, 444, 41-53.

Schacter, D. L. (1986). A psychological view of the neurobiology of memory. In L. LeDoux \& W. Hirst (Eds.), Mind and brain: Dialogues in cognitive neuroscience. Cambridge: Cambridge University Press.

Schacter, D. L. (1987). Implicit memory: History and current status. Journal of Experimental Psychology: Learning, Memory, \& Cognition, 13, 501-518.

Schacter, D. L. (1990). Perceptual representation systems and implicit memory: Toward a resolution of the multiple memory systems debate. In A. Diamond (Ed.), Development of neural bases of higher cognition. Annals of the New York Academv of Sciences 608, 435-571.

Schacter, D. L., Cooper, L. A., \& Delaney, S. (1990). Implicit memory for unfamiliar objects depends on access to structural descriptions. Ioumal of Experimental Psuchology: General. 119, 5-24.

Schacter, D. L., Cooper, L. A., Tharan, M., \& Rubens, A. B. (1991). Preserved priming of novel objects in patients with memory disorders. Journal of Neuroscience, in press.

Schacter, D. L., \& Graf, P. (1986). Preserved learning in amnesic patients: Perspectives from research on direct priming. Journal of Clinical and Experimental Neurotswchology, 8 , 727-743.

Schacter, D. L., \& Graf, P. (1989). Modality specificity of implicit memory for new associations. Journal of Experimental Psychology: Learning, Memory and Cognition, 15, 312.

Schacter, D. L., \& Nadel, L. (1991). Varieties of spatial memory: A problem for cognitive neuroscience. In $\mathrm{H}$. Weingartner \& R. Lister (Eds.), Cognitive neuroscience. New York: Oxford University Press. In press.

Seltzer, B., \& Benson, D.F. (1974). The temporal pattern of retrograde amnesia in Korsakoff's disease. Neurology, 24 527-530. 
Semon, R. (1904/21). The mneme. London: George Allen \& Unwin.

Semon, R. (1909/1923). Mnemic psycbology. London: George Allen \& Unwin.

Sherrington, C. S. (1906). The integrative action of the nervous system. New York: Scribner.

Sherry, D. F., \& Schacter, D. L. (1987). The evolution of multiple memory systems. Pswchological Review 94, 439-454.

Shiffrin, R. M., \& Atkinson, R. C. (1969). Storage and retrieval processes in long-term memory. Psychological Review, $76(2), 179-193$

Shimamura, A. P. (1985). Problems with the finding of stochastic independence as evidence for multiple memory systems. Bulletin of the Psychonomic Society, 23(6), 506-508.

Shimamura, A. P. (1986). Priming effects in amnesia: Evidence for a dissociable memory function. The Quarterly Journal of Experimental Psychology, 38A, 619-644.

Shimamura, A. P. (1989). Disorders of memory: The cognitive science perspective. In F. Boller \& J. Grafman (Eds.), Handbook of neuropsychology (Vol. 3). Amsterdam: Elsevier Science Publishers B.V.

Singley, M. K., \& Anderson, J. R. (1989). The transfer of cognitive skill. Cambridge, MA: Harvard University Press.

Spurzheim, J. G. (1834). Phrenology: The doctrine of mental phenomena. Boston: Marsh, Capen, and Lyon.

Squire, L. R. (1980). Specifying the deficit in human amnesia: Storage, retrieval and semantics. Neuropsychologia. 18 368-372.

Squire, L. R. (1986). Mechanisms of memory. Science, 232, 1612-1619.

Squire, L. R. (1987). Memory and brain. New York: Oxford University Press.

Squire, L. R., \& Cohen, N. J. (1979). Memory and amnesia: Resistance to disruption develops for years after learning. Behavioral and Neural Biology 25, 115-125.

Squire, L. R., Cohen, N. J., \& Nadel, L. (1984). The medial temporal region and memory consolidation: A new hypothesis. In H. Weingarner \& E. Parker (Eds.), Memory consolidation. Hillsdale, NJ: Lawrence Erlbaum.

Squire, L. R., \& Frambach, M. (1990). Cognitive skill learning in amnesia. Psychobiology, 18(1), 109-117.

Squire, L. R., Slater, P. C., \& Chace, P. M. (1975). Retrograde amnesia: Temporal gradient in very long-term memory following electroconvulsive therapy. Science 187, 77-79.

Squire, L. R., \& Spanis, C.W. (1984). Long gradient of retrograde amnesia in mice: Continuity with the findings in humans. Behavioral Neuroscience, 98, 345-348.

Stellar, E. (1957). Physiological psychology. Anmual Review of Psvchology, 8, 415-436.

Sutherland, R. J., \& Rudy, J. W. (1989). Configural association theory: The role of the hippocampal formation in learning, memory, and amnesia. Psychobiology, 17(2), 129-144

Thompson, R. (1958). The effect of intracranial stimulation on memory in cats. Joumal of Comparative and Pbysiological Psychology, 51, 421-426.

Thompson, R. (1976). The search for the engram. American Psychologist, 31(3), 209-227.

Thompson, R., \& Pryer, R. S. (1956). The effect of anoxia on retention of a discrimination habit. Journal of Comparative and Physiological Psychology, 49, 297-300.

Tolman, E. C. (1948). Cognitive maps in rats and men. $\underline{P_{S Y}-}$ chological Review 55, 189-208.

Tolman, E. C. (1949). There is more than one kind of learning. Psychological Review 56(3), 144-155.

Tulving, E. (1972). Episodic and semantic memory. In E. Tulving \& W. Donaldson (Eds.), Organization of memory. New York: Academic Press.

Tulving, E. (1983). Elements of episodic memory. Oxford: Clarendon Press.
Tulving, E. (1984). Précis of Elements of episodic memory. The Bebavioral and Brain Sciences, 7, 223-268.

Tulving, E., \& Bower, G. H. (1974). The logic of memory representations. In G. H. Bower (Ed.), The Psychology of Learning and Motivation Vol. 8. New York: Academic Press.

Tuvling, E., Hayman C. A. G., \& MacDonald, C. (1991). Longlasting perceptual priming and semantic learning in amnesia: A case experiment. Journal of Experimental Psychology: Learning, Memory, and Cognition. In press

Tulving, E., \& Schacter, D. L. (1990). Priming and human memory systems. Science, 247, 301-306.

Tulving, E., Schacter, D. L., \& Stark, H. (1982). Priming effects in word-fragment completion are independent of recognition memory. Joumal of Experimental Psuchologv. Leaming Memory \& Cognition, 8, 336-342.

Underwood, B. J. (1969). Attributes of memory. Esvchological Review, 76, 559-573

van Heerden, P. J. (1963). Theory of optical information storage in solids. Antlied Otics 2(4), 393-400.

Warrington, E. K. (1982). The double dissociation of shortand long-term memory deficits. In L. Cermak (Ed.), Human memory and amnesia. Hillsdale, NJ: Lawrence Erlbaum.

Warrington, E. K., \& Weiskrantz, L. (1968). New method of testing long-term retention with special reference to amnesic patients. Nature (London), 217, 972-974.

Warrington, E. K., \& Weiskrantz, L. (1970). Amnesic syndrome Consolidation or retrieval? Nature (London), 228, 628-630.

Warrington, E. K., \& Weiskrantz, L. (1974). The effect of prior learning on subsequent retention in amnesic patients. Neuropsychologia, 12, 419-428.

Watkins, M. (1978). Theoretical issues. In M. M. Gruneberg \& P. Morris (Eds.), Aspects of memory. London: Methuen.

Weiskrantz, L. (1966). Experimental studies in amnesia. In C.M.W. Whitty \& O.L. Zangwill (Eds.), Amnesia. London: Butterworth.

Weiskrantz, L. (1989). Remembering dissociations. In H. L. Roediger, III \& F. I. M. Craik (Eds.), Varieties of memory and consciousness: Essays in bonour of Endel Tulving. Hillsdale, NJ: Lawrence Erlbaum.

Wernicke, K. (1874). Der aphasische Symptomenkomplex. Breslau. Transl. In Boston Studies in Pbilosopby of Science, 4, 34-97.

Wheeler, R. H., \& Perkins, F. T. (1932). Principles of mental development. New York: Thomas Y. Crowell.

Wicklegren, W. A. (1979). Chunking and consolidation: A theoretical synthesis of semantic networks, configuring in conditioning, $S-R$ vs cognitive learning, normal forgetting, the amnesic syndrome and the hippocampal arousal system. Psuchological Review 86, 44-60.

Widrow, B., \& Hoff, M. E. (1960). Adaptive switching circuits. 1960 IRE WESCON Convention Record. New York: IRE, pp. 96-104

Winocur, G. (1990). Anterograde and retrograde amnesia in rats with dorsal hippocampal or dorsmedial thalamic lesions. Behavioural Brain Research 38, 145-154.

Woodworth, R. S. (1929). Psychology. New York: Henry Holt.

Zangwill, O. L. (1963). The cerebral localisation of psycholog ical function. Advances in Science, 20, 335-344.

Zola-Morgan, S. M., \& Squire, L. R. (1985). Complementary approaches to the study of memory: Human amnesia and animal models. In N. M. Weinberger, J. L. McGaugh, \& G. Lynch (Eds.), Memory systems of the brain: Animal and buman cognitive processes. New York: Guilford Press.

Zola-Morgan, S. M., \& Squire, L.R. (1990). The primate hippocampal formation: Evidence for a time-limited role in memory storage. Science 250, 288-290.

Zubin, J., \& Barrera, S.E. (1941). Effect of electric convulsive therapy on memory. Proceedings of the Society of Experimental Biology and Medicine, 48, 596-597 (Abstract). 


\section{This article has been cited by:}

1. Gabriele Janzen, Clemens Jansen, Miranda van Turennout. 2008. Memory consolidation of landmarks in good navigators. Hippocampus 18:1, 40-47. [CrossRef]

2. B. Berberian, M. D. Giraudo. 2006. Dynamic variability in mnemic systems: a way to study the consolidation process. Cognitive Processing 7:S1, 15-17. [CrossRef]

3. Stanley B. Klein, Leda Cosmides, John Tooby, Sarah Chance. 2002. Decisions and the evolution of memory: Multiple systems, multiple functions. Psychological Review 109:2, 306-329. [CrossRef]

4. David I. Mostofsky. 2001. Models and methods for studying behavior in polyunsaturated fatty acid research. Lipids 36:9, 913-917. [CrossRef]

5. Lynn Nadel, Veronique Bohbot. 2001. Consolidation of memory. Hippocampus 11:1, 56-60. [CrossRef]

6. Shang-Peng Wu, Kwok-Tung Lu, Wen-Chang Chang, Po-Wu Gean. 1999. Involvement of mitogen-activated protein kinase in hippocampal long-term potentiation. Journal of Biomedical Science 6:6, 409-417. [CrossRef]

7. Stanley B. Klein, John F. Kihlstrom. 1998. On Bridging the Gap Between Social-Personality Psychology and Neuropsychology. Personality and Social Psychology Review 2:4, 228-242. [CrossRef]

8. Howard Eichenbaum. 1997. DECLARATIVE MEMORY: Insights from Cognitive Neurobiology. Annual Review of Psychology 48:1, 547-572. [CrossRef]

9. B. Bontempi, R. Jaffard, C. Destrade. 1996. Differential Temporal Evolution of Post-Training Changes in Regional Brain Glucose Metabolism Induced by Repeated Spatial Discrimination Training in Mice: Visualization of the Memory Consolidation Process?. European Journal of Neuroscience 8:11, 2348-2360. [CrossRef]

10. CRISTINA M. ALBERINI, MIRELLA GHIRARDI, YAN-YOU HUANG, PETER V. NGUYEN, ERIC R. KANDEL. 1995. A Molecular Switch for the Consolidation of Long-Term Memory: cAMP-Inducible Gene Expression. Annals of the New York Academy of Sciences 758:1 DNA, 261-286. [CrossRef]

11. Viviane Pallage, Beat Knusel, Franz Hefti, Bruno Will. 1993. Functional Consequences of a Single Nerve Growth Factor Administration Following Septal Damage in Rats. European Journal of Neuroscience 5:6, 669-679. [CrossRef]

12. Lynn Nadel. 1992. Multiple Memory Systems: What and WhyMultiple Memory Systems: What and Why. Journal of Cognitive Neuroscience 4:3, 179-188. [Abstract] [PDF] [PDF Plus]

13. Larry R. Squire. 1992. Declarative and Nondeclarative Memory: Multiple Brain Systems Supporting Learning and MemoryDeclarative and Nondeclarative Memory: Multiple Brain Systems Supporting Learning and Memory. Journal of Cognitive Neuroscience 4:3, 232-243. [Abstract] [PDF] [PDF Plus]

14. Daniel L. Schacter. 1992. Priming and Multiple Memory Systems: Perceptual Mechanisms of Implicit MemoryPriming and Multiple Memory Systems: Perceptual Mechanisms of Implicit Memory. Journal of Cognitive Neuroscience 4:3, 244-256. [Abstract] [PDF] [PDF Plus]

15. Craig H. Bailey, Eric R. KandelSynaptic and Cellular Basis of Learning . [CrossRef] 